
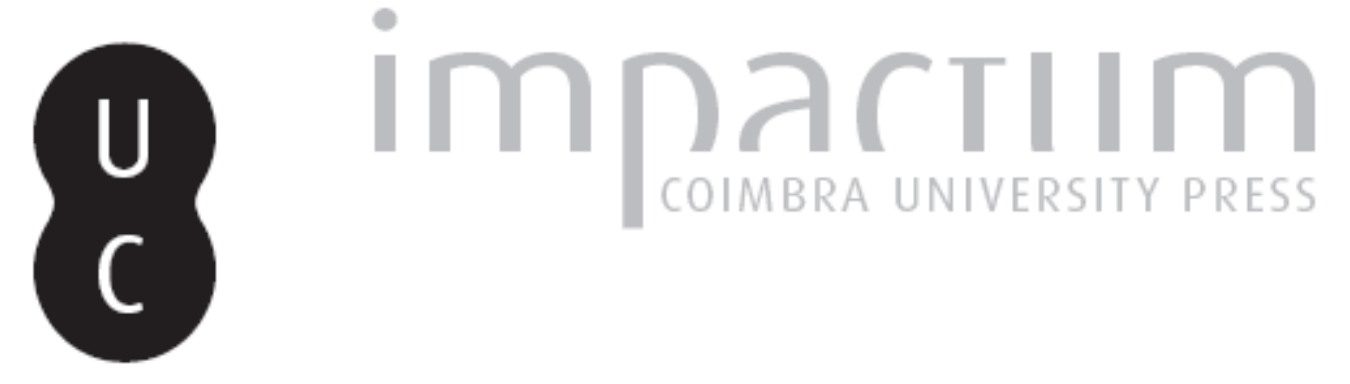

Luís de Magalhães, Oliveira Martins e a "Vida Nova"

Autor(es): $\quad$ Santos, Miguel António Dias

Publicado por: Imprensa da Universidade de Coimbra

URL persistente:

URI:http://hdl.handle.net/10316.2/43722

DOI:

DOI:https://doi.org/10.14195/2183-8925_24_9

Accessed : $\quad$ 26-Apr-2023 16:22:00

A navegação consulta e descarregamento dos títulos inseridos nas Bibliotecas Digitais UC Digitalis, UC Pombalina e UC Impactum, pressupõem a aceitação plena e sem reservas dos Termos e Condições de Uso destas Bibliotecas Digitais, disponíveis em https://digitalis.uc.pt/pt-pt/termos.

Conforme exposto nos referidos Termos e Condições de Uso, o descarregamento de títulos de acesso restrito requer uma licença válida de autorização devendo o utilizador aceder ao(s) documento(s) a partir de um endereço de IP da instituição detentora da supramencionada licença.

Ao utilizador é apenas permitido o descarregamento para uso pessoal, pelo que o emprego do(s) título(s) descarregado(s) para outro fim, designadamente comercial, carece de autorização do respetivo autor ou editor da obra.

Na medida em que todas as obras da UC Digitalis se encontram protegidas pelo Código do Direito de Autor e Direitos Conexos e demais legislação aplicável, toda a cópia, parcial ou total, deste documento, nos casos em que é legalmente admitida, deverá conter ou fazer-se acompanhar por este aviso. 

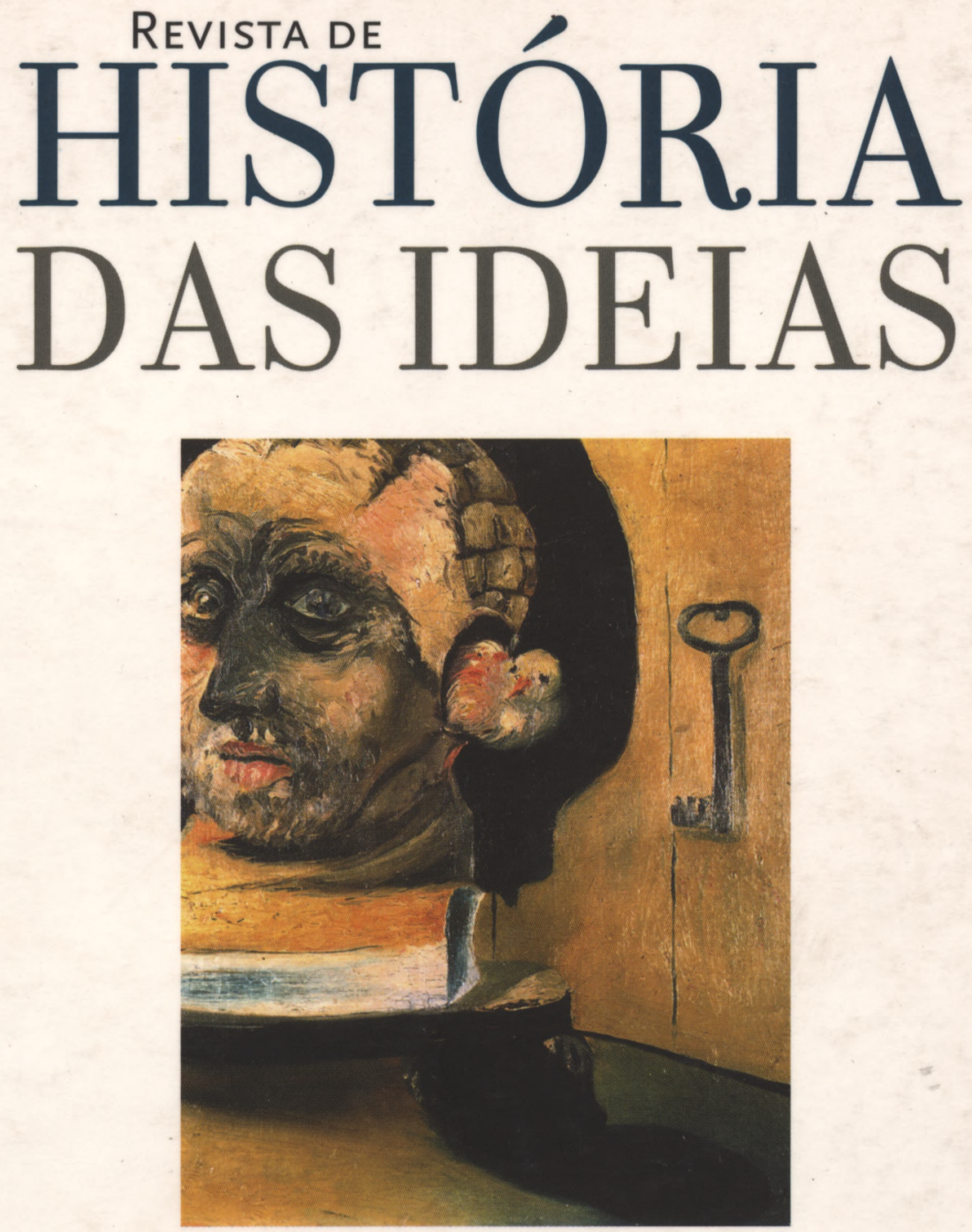

OS INTELECTUAIS E OS PODERES

Volume 24, 2003

INSTITUTO DE HISTÓRIA E TEORIA DAS IDEIAS

Faculdade de Letras da Universidade de Coimbra 


\title{
LUÍS DE MAGALHÃES, OLIVEIRA MARTINS E A "VIDA NOVA"
}

\begin{abstract}
A concatenação do reformismo da "Vida Nova" com a sua herança natural, protagonizada pelo franquismo, será melhor compreendida quando articulada com um conhecimento mais profundo do envolvimento político e ideológico de Luís de Magalhães nos dois movimentos. Adepto do proselitismo reformista encabeçado por Oliveira Martins e pelo seu projecto conhecido por "Vida Nova", Magalhães assumirá mais tarde um papel de destaque enquanto teorizador e ideólogo das propostas de reforma do Estado conotadas com o franquismo, dando continuidade a alguns dos pressupostos político-ideológicos em que assentou o projecto reformador martiniano.

A opção de iniciar este estudo recorrendo às relações que manteve com Oliveira Martins está assim em parte justificada. Prende-se necessariamente com imperativos cronológicos, assumidos pela necessidade de averiguar o momento em que Luís de Magalhães emerge como político e intelectual. De facto, entre 1881 e 1894, data em que faleceu o historiador, foram ambos cúmplices numa intensa actividade política e ideológica. Oliveira Martins apresentava-se, então, como candidato a reformador das instituições liberais, arrastando consigo uma plêiade de notáveis. Luís de Magalhães será um dos mais fervorosos discípulos deste proselitismo reformista. Estamos certos que o contacto com a historiografia
\end{abstract}

* Mestre em História Contemporânea pela Universidade de Coimbra. Doutorando. 
de Oliveira Martins, com as suas opções políticas e ideológicas, e o convívio pessoal, no âmbito das tertúlias literárias em que se reuniram os amigos do historiador, contribuíram significativamente para a formação da estrutura intelectual e política de Luís de Magalhães e para a organização do quadro de valores em que estribará a sua acção política e doutrinária.

\section{A Adesão à "Vida Nova"}

1. Luís de Magalhães conheceu Oliveira Martins, no Porto, em Abril de $1881^{(1)}$, quando era ainda estudante de Direito em Coimbra, percurso inevitável para os candidatos a uma carreira política. Entre as obrigações estudantis e o bulício de profusas tertúlias literárias ${ }^{(2)}$, a sua geração académica ainda encontrou energias para integrar a homenagem pública a Camões e a Pombal, organizando as festividades cívicas com que a academia comemorou o centenário da morte de ambos. Sob os auspícios patrióticos do Épico, Luís de Magalhães, que participou activamente na organização dos festejos, ao lado dos seus amigos Carlos Lobo d'Ávila,

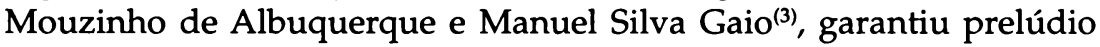
substancial para a solene sagração da sua vocação lírica ${ }^{(4)}$.

(1) Cf. Miranda de Andrade, O Escritor Luís de Magalhães, Sep. do Boletim da Biblioteca Pública Municipal de Matosinhos, Matosinhos, $\mathrm{n}^{\circ} 17,1970$, p. 23.

(2) "Não sei quantas revistas literárias fundámos - revistas efémeras que uma singular fatalidade matava (parece que sistematicamente) ao terceiro número" (O Primeiro de Janeiro, XXVII ano, $\mathrm{n}^{\circ} 241,9$ Out. 1895, p. 1).

(3) Todos farão parte da Comissão Executiva que organizou os festejos académicos. Em carta enviada a Joaquim Martins de Carvalho, director do jornal Conimbricense, a Comissão Executiva afirmou: "Vimos oferecer-lhe um lugar [...] saudando a memória daquele que pôs toda a inspiração do seu génio e toda a fortaleza do seu braço ao serviço da Pátria. E é para honrar o nome de Camões, que é afirmação da nacionalidade portuguesa, nome tão grande como o de Homero, que os estudantes da Universidade impetram o auxílio da Imprensa de Coimbra"( $O$ Conimbricense, $\mathrm{n}^{\circ} 3426,5$ Jun. 1880, p. 2).

(4) De facto, em Maio de 1881, a academia inaugurou em Coimbra um monumento ao Épico, tendo Magalhães declamado o seu poema As Navegações, no Teatro Académico, que seria impresso no mesmo ano. Sobre os referidos festejos, veja-se Programa dos Festejos Académicos para a Inauguração do Monumento a Luís de Camões, Coimbra, Imprensa da Universidade, 1881. 
Por esta altura, o historiador ainda não havia mergulhado na política activa, preocupado com a construção da sua "Biblioteca das Ciências Sociais", ao mesmo tempo que estreitava relações com a burguesia portuense.

O encontro de ambos aconteceu na sede da Sociedade de Geografia Comercial do Porto, sob o patrocínio simbólico de Luís de Camões. De facto, a sensibilidade poética, organizada em torno da interpretação nacionalista do Épico, será o estímulo para a crescente comunhão de ideais e valores entre ambos. A poesia garantirá o enlace dos dois amigos em torno da ideia de "patriotismo", que evoluirá em Luís de Magalhães para um exacerbado nacionalismo político e literário, muito em voga no final do século XIX.

Enquanto em Lisboa as celebrações camonianas eram aproveitadas pelo Partido Republicano para afirmar o seu credo, no Porto animaram uma elite de políticos, burgueses e intelectuais a encabeçar um "vincado protesto contra a marcha dos negócios públicos"(5). Foi a partir deste movimento, dinamizado pela imprensa da cidade, que resultou a fundação da Sociedade de Geografia Comercial do Porto, idealizada para a concretização de avultadas realizações de ordem económica e social ${ }^{(6)}$. Oliveira Martins, que presidirá durante algum tempo a tão laboriosa instituição, será o grande dinamizador deste grémio de notáveis do Norte que ambicionava "dar vitalidade à sociedade portuguesa para que saia do letargo em que está mergulhada"(7). Ainda que diferenciadas nos objectivos a perseguir, as reacções expostas resultavam do crescente descontentamento social. No plano político, o liberalismo monárquico

(5) Cf. F. A. Oliveira Martins, O Socialismo na Monarquia, Lisboa, Parceria António Maria Pereira, 1944, p. 25.

(6) Ambicionava contribuir para o progresso material das gentes do Norte, nomeadamente através da elaboração de inquéritos e relatórios sobre as actividades económicas da região. Para uma análise dos objectivos da Sociedade, veja-se António Álvaro Dória, Oliveira Martins e a Sociedade de Geografia Comercial do Porto, Separata do Boletim Cultural da Câmara Municipal do Porto, Porto, vol. XVII, 1954; F. A. Oliveira Martins, ob. cit., p. 27.

(7) In Boletim da Sociedade de Geografia Comercial do Porto, Porto, $2^{a}$ série, $n^{\circ} 4$, 1884. O texto é da autoria de José Augusto Correia de Barros, antigo ministro e um dos fortes representantes do Partido Progressista no Porto. Tal facto confirma que as ligações de Oliveira Martins a alguns dos mais eminentes dirigentes do Partido Progressista terão começado no seio da Sociedade de Geografia. 
via-se conotado com um certo imobilismo, com a manutenção do rotativismo a acendrar os espíritos mais democráticos e, em particular, os republicanos. No plano económico, o lento esgotamento do modelo económico fontista, assente no aumento contínuo da dívida pública e do défice orçamental ${ }^{(8)}$, só beneficiava as oligarquias económicas e financeiras, ao mesmo tempo que conservava a dependência financeira do país em relação ao estrangeiro. $O$ tratado de Lourenço Marques, assinado em 1879 e proposto para ratificação em 1881, acirrou o descontentamento da opinião pública contra o rei e a monarquia, com o argumento de que este configurava uma extensa relação de cedências à Inglaterra que causariam a ruína do país, senão mesmo a perda da sua independência política. A polémica estimulará a formação de um exacerbado nacionalismo colonialista, de feição marcadamente antidinástica, pois foi vivamente protagonizado pelas facções republicanas ${ }^{(9)}$.

A participação de Luís de Magalhães na Sociedade de Geografia Comercial do Porto, onde desempenhou as funções de secretário do Boletim editado pela Sociedade, traduziu-se num fraco envolvimento ${ }^{(10)}$. Acabado de sair da Universidade, o jovem jurista ocupava o seu tempo a compor versos enquanto sonhava vagamente com a carreira de diplomata $^{(11)}$. Do surto criador dessa época resultará a publicação, em 1884, do livro de poesia Odes e Canções, apadrinhado com um sentido prólogo de Oliveira Martins em que enaltece a sua "imaginação, [que] deleitando-se no campo das emoções naturais, tenta voar e voa para o campo mais largo das emoções morais" ${ }^{\prime \prime(12)}$. Ainda no campo da literatura, dará à

(8) Só entre 1886 e 1890, durante o consulado progressista de Luciano de Castro, o défice orçamental chegou a atingir os 15000 contos.

(9) Sobre a polémica em torno da assinatura do tratado, veja-se Valentim Alexandre, "Nação e Império", in História da Expansão Portuguesa (Dir. de Francisco Bethencourt e Kirti Chandhuri), vol. 4, Lisboa, Círculo de Leitores, pp. 119-122.

${ }^{(10)}$ Integrou a comissão que preparou o Projecto de Regulamento da Sociedade, discutido na sessão de 26 de Março de 1883, ao lado de Oliveira Martins. Cf. Boletim da Sociedade de Geografia Comercial do Porto, vol. II, Porto, Secretaria da Sociedade de Geografia Comercial, 1883-1885, p. 144.

(11) Cf. Miranda de Andrade, ob. cit., p. 26

${ }^{(12)}$ P. XXII. Eça de Queirós, a propósito do poema D. Sebastião, que já circulava entre os seus amigos, avisava Magalhães contra os conselhos de Martins: "Parabéns pelo assunto do $D$. Sebastião. Nenhum mais belo, mais patriótico, mais poético. Mas, por quem é, trabalhe-me essa forma! Pule-a, cinzele-a, cristalize-a! Não se deixe levar pelas teorias abomináveis do amigo Oliveira Martins, sobre a 
estampa o romance $O$ Brasileiro Soares (1886) que contará com o conhecido prefácio de Eça de Queirós, em que este lhe exalta o mérito de haver procedido a uma "verdadeira reabilitação social" do português emigrado para o Brasil ${ }^{(13)}$. Quer isto dizer que a estreia literária de Magalhães encontrou eco junto dos seus amigos, numa época em que era usual os candidatos a literatos se ancorarem em escritores já consagrados. Compreende-se. No estrito meio intelectual e literário oitocentista, em que quase todos os letrados se conheciam, os laços de amizade eram responsáveis por grande parte das recensões críticas surgidas na imprensa e dos inevitáveis prefácios e proémios com que se exaltavam as virtudes estéticas e criativas dos autores ${ }^{(14)}$. Entre a geração de 70 esta prática resultou numa espécie de solidariedade intelectual e de cumplicidade afectiva ímpares na história da cultura em Portugal ${ }^{(15)}$.

Ora todos os factos enunciados acerca da vida literária do jovem escritor se inscrevem no período em que a casa de Oliveira Martins se tornara o centro de contacto dos intelectuais que haviam frequentado o Cenáculo. À volta de Antero de Quental, Guerra Junqueiro, Ramalho Ortigão e Eça de Queirós juntava-se agora na aventura intelectual jovens como Carlos Lobo d'Ávila, Marçal Pacheco e Luís de Magalhães, num convívio que os fará herdeiros dos seus ideais, todos orgulhosos do sentimento de pertença a uma elite superior ${ }^{(16)}$. Por sua vez, o autor de

sinceridade da emoção. O sentimento mais artificial, posto num verso maravilhosamente feito, é uma obra de arte; o mais verdadeiro grito de paixão, num alexandrino desajeitado, é uma sensaboria. Só há beleza onde há ordem" (Correspondência, leitura, prefácio e notas de Guilherme de Castilho, Lisboa, Biblioteca de Autores Portugueses, 1983, p. 234; sublinhado no original). Na segunda parte do livro, o candidato a poeta publicou odes dedicadas aos seus heróis literários da época: Oliveira Martins, Eça de Queirós, Antero de Quental, Guerra Junqueiro e Teófilo Braga.

(13) P. XVIII.

${ }^{(14)}$ Cf. a carta de Eça de Queirós a Luís de Magalhães, na qual o escritor lhe agradece a crítica produzida por este na Província a propósito da publicação da Relíquia, in Obras de Eça de Queirós - Correspondência, Lisboa, Livros do Brasil, s.d., pp. 105-108.

${ }^{(15)}$ Cf. António José Saraiva, A Tertúlia Ocidental, $2^{\mathrm{a}}$ ed., Lisboa, Gradiva, pp. 11-14.

${ }^{(16)}$ Cf. F. A. Oliveira Martins, ob. cit., p. 34. 
As Navegações recebia alguns dos seus amigos intelectuais, com destaque para Martins, Antero e Eça, no palheiro da Costa Nova, a antiga residência de praia de José Estêvão, situada nas proximidades de Aveiro ${ }^{(17)}$.

Aí se cimentará uma amizade que extravasará os limites da simples relação afectiva, em direcção a projectos literários e aventuras políticas. Entre as margens, então abundantes de caça, da ria de Aveiro erguer-se-á aos poucos uma cumplicidade espiritual de que o historiador deixará viva expressão em carta ao seu jovem amigo, adornada por referências à simbólica sebastianista: "Meu caro sebastianista: [...] A costa nova foi a nossa jornada de África - Sem Alcácer Quibir. Mas ficou-nos a todos a viva saudade desses bons e breves dias - um sebastianismo que se traduz para nós na vaga esperança de no futuro podermos ir deitar ferro na ria de Aveiro, à borda do mar, com uma caçadeira para os mergulhões, um barco [...] e o sossego impagável desse cantinho em que a gente esquece o mundo"(18). Pouco tempo depois desta carta ter sido escrita os dois amigos iniciavam o movimento reformista conhecido por "Vida Nova".

2. Para a história deste período têm contribuído os escritos que Luís de Magalhães nos legou, sejam registos coevos ou panegíricos biográficos. Nas páginas do Diário da Vida Nova, manuscrito providencial do movimento, como no "Prefácio" aos Perfis, de Oliveira Martins, têm os historiadores e memorialistas encontrado terreno fértil para a intelecção dos meandros políticos em que se forjou o movimento, bem como da radical mutação política e mental que se operou no espírito do historiador $^{(19)}$. Com base nestes registos, foi possível compreender a sua adesão às "formas conservadoras do estatismo e dos princípios do socialismo

(17) Cf. F. A. Oliveira Martins, Oliveira Martins e os seus Contemporâneos, Lisboa, Guimarães Editores, 1960, p. 69.

(18) Biblioteca Nacional de Lisboa, Espólio de Luís de Magalhães, 1884, E2/cx.1/ doc. 123. "A Costa Nova teve o condão de acordar em nós todos um lirismo que já não nos é próprio. Creia que até o Antero, esse profeta assírio, que passa a vida afligindo-se em busca de impassibilidade, até ele veio encantado" [Ibidem].

${ }^{(19)}$ Nomeadamente o livro já citado de F. A. Oliveira Martins, O Socialismo em Oliveira Martins e o trabalho de A. Álvaro Dória, No centenário da "Vida Nova", sep. do Boletim de Trabalhos Históricos, Guimarães, 1986, fazem transcrições directas do Diário. Apesar de algum esforço nesse sentido não nos foi possível identificar o actual paradeiro do manuscrito. 
catedrático" (20) bem como a emergência de um certo messianismo político ditado por imposições recentes do seu pragmatismo filosófico: o pensador e o observador da realidade social era instado a trocar a reflexão teórica pela acção política concreta porque - como o próprio confidenciava a Magalhães - "uma nação, em marcha para uma crise grave [...] não se salva com ideias formuladas em livros: salva-se, sim, mas com ideias realizadas em actos" ${ }^{\prime 21)}$.

Consciente da inevitabilidade de encontrar dentro do regime monárquico as soluções políticas para garantir a concretização do seu projecto reformista, Oliveira Martins opta pela incursão no Partido Progressista, arrastando consigo Luís de Magalhães e outros crentes no seu messianismo ${ }^{(22)}$. A sedução da política, num jovem com naturais ambições e que carregava o peso da tradição paterna ${ }^{(23)}$, acontecia sob o efeito do projecto reformador e morigerador de Oliveira Martins, o mais adequado à sua natureza idealista.

(20) Luís de Magalhães, "Prefácio", in Oliveira Martins, Perfis, Lisboa, Parceria António Maria Pereira, 1930, p. XXI. Para a compreensão da superação do seu republicanismo federalista e socializante por troca com o socialismo catedrático, veja-se Fernando Catroga, O Problema Político em Antero de Quental. Um Confronto com Oliveira Martins, sep. da Revista de História das Ideias, Coimbra, vol. III, 1981, pp. 89-91.

(21) Idem, ibidem, p. XXVII. Para Luís de Magalhães, este desejo de intervenção política estaria associado aos contactos com os meios económicos e a política oficial que aconteceram durante a sua passagem pela Sociedade de Geografia Comercial do Porto e pela sua colaboração no inquérito industrial de 1882: "Familiarizado, assim, com as esferas produtoras e administrativas, nas quais conquistara uma reputação de alta competência, não era de estranhar que o seduzisse a ideia de [...] fazer sentir nelas a acção benéfica do seu saber e do seu espírito organizador" (idem, ibidem, p. XXV).

(22) As razões que explicam o seu proselitismo progressista deixou-as Magalhães gravadas no seu Diário: "a sua resolução de entrar para o partido progressista, a ver se por meio da acção dum futuro governo desta cor política, seria possível introduzir no país algumas ou todas as reformas financeiras e económicas, indispensáveis para desanuviar o nosso futuro, seriamente comprometido pela desordenada marcha das coisas públicas" (transcrição feita por A. Álvaro Dória, ob. cit., pp. 7-8).

(23) Cf. Carta de Luís de Magalhães a Rita Miranda de Magalhães, de 2 de Março de 1879, BNL, Espólio de Luís de Magalhães, E2/cx. 36. Luís de Magalhães não conheceu o pai, pois este morreu em 1862, contando aquele cerca de três anos. 
Por esta altura, o Partido Progressista, liderado pelo velho Anselmo Braamcamp, encontrava-se enfraquecido pelas disputas internas das diferentes facções que o constituíam, como acontecia no Porto, dividido entre Joaquim Barros Gomes, Presidente da Câmara Municipal da cidade, e Tomás Lobo, antigo governador civil do distrito ${ }^{(24)}$. Oliveira Martins terá optado por esta solução, pois considerava o progressismo o legítimo herdeiro do reformismo setembrista e da patuleia ${ }^{(25)}$. Daí o entusiasmo com que procurou convencer o velho dirigente da importância de renovação do programa do Partido, convertendo-o ao reformismo social e económico inspirado no socialismo de Estado bismarkiano ${ }^{(26)}$.

A adesão solene de Oliveira Martins e Luís de Magalhães ao Partido Progressista ocorreu durante uma assembleia dos seus correligionários reunida no Porto em 25 de Abril de 1885, no salão do antigo Teatro do Príncipe Real. Numa sala repleta de progressistas desconfiados, os dois amigos, juntamente com Correia de Barros e Delfim Oliveira Maia, seus corifeus na Sociedade de Geografia Comercial do Porto, procuraram converter os partidários de Anselmo Braamcamp ao reformismo socialista que representavam. A tarefa adivinhava-se difícil. A hostilidade do séquito comprometido com Tomás Lobo não dava tréguas, numa antecipação de embaraços futuros: "Recordo-me bem da frieza dessa reunião. Havia em todos um vago ar de desconfiança. 'Que quererá este homem?' parece que a cada um perguntava a si próprio. Apenas um ou outro amigo, excitava os aplausos tardios e fracos com interrupções aqui e

(24) Para Magalhães, "as dissensões lavravam fundamente e acabaram por se agravar com o caso dos sindicatos de Salamanca, que separou absolutamente os dois grupos que desde há tempos se iam desenhando, no correr das intrigas que iam dilacerando o partido" (extraído por A. Álvaro Dória, ob. cit., p. 27).

(25) Sobre o significado desta interpretação, veja-se Fernando Catroga, ob. cit., pp. 93-94. A criação de um novo partido político poderá ter sido equacionada, mas as condições políticas da época não o proporcionavam. A nova agremiação, germinada no seio do "oliveirismo", elitista na sua concepção e formação, pois englobaria em torno do seu programa "os elementos sãos da opinião e todos os interesses legítimos", estaria condenada ao fracasso: "não passaria d'um partido académico, uma tertúlia de intelectuais, doutrinando e apostolando no vácuo, um quadro de oficiais sem soldados, de dirigentes sem massas eleitorais, sem forças políticas efectivas em que se apoiassem (Luís de Magalhães, "Prefácio", in Oliveira Martins, ob. cit., p. XXVIII).

${ }^{(26)}$ Cf. F. A. Oliveira Martins, ob. cit., pp. 40-41. 
além. Para um ânimo menos forte, bastaria aquele desolador aspecto de indiferença pública, para o fazer imediatamente retirar-se e para lhe tirar toda a esperança"(27).

A esperança de Oliveira Martins residia, contudo, num vasto programa reformista sintetizado no seu livro Política e Economia Nacional, publicado em 1885. Numa análise perfunctória, diremos apenas que aí se encontram consignados os pressupostos teóricos do intervencionismo estatal com vista à aplicação de um modelo de desenvolvimento assente no nacionalismo económico e no proteccionismo aduaneiro ${ }^{(28)}$, sendo que o plano das reformas políticas se subordinaria às realizações nas esferas económico-financeira e social.

Neste movimento reformista participou activamente Luís de Magalhães, não só como redactor do jornal $A$ Província ${ }^{(29)}$, órgão do movimento desde 25 de Maio de 1885, data em que saiu o primeiro número, como em tarefas específicas para o que o incumbiu Oliveira Martins ${ }^{(30)}$. Verdadeiramente

(27) Diário da Vida Nova, transcrição de A. Álvaro Dória, ob. cit., p. 34. Diferente foi o comportamento dos progressistas reunidos durante o congresso do Partido, a 17 de Julho, presidido por Anselmo de Braamcamp, como demonstra a descrição que nos deixou Oliveira Martins: "Um teatro enorme coalhado de gente, os velhos junto dos moços, os pobres junto dos ricos, os grandes junto dos humildes, os ilustres dos obscuros, abraçados todos numa aspiração, num desejo, num entusiasmo e numa indignação comum eis aí o que foi a reunião de ontem" (A Província, Lisboa, Guimarães Editores, 1958, p. 101). Luís de Magalhães, que participou activamente no congresso, havia sido preparado por Martins para que este terminasse em apoteose: "Na sessão de amanhã V. há-de ser interpelado directamente acerca das tradições de seu pai, etc. Recomponha pois o seu esplêndido brinde de outro dia para concluir com um bouquet quente o congresso do novo partido" (BNL, Espólio de Luís de Magalhães, E2/cx.1/doc. 123).

${ }^{(28)}$ Cf. Fernando Catroga, ob. cit., pp. 94-95. Para uma análise geral do movimento e suas consequências, veja-se Rui Ramos, "A Segunda Fundação", in José Mattoso [dir.], História de Portugal, vol. 6, Lisboa, Círculo de Leitores, 1994, pp. 125-297.

(29) Os artigos que escreveu para A Província foram reunidos e publicados com o título Notas e Impressões (Artes e Letras - Política e Costumes), Porto, Livraria Portuense, 1890.

(30) Com efeito, a elaboração e apresentação, em 1887, do Projecto de Lei de Fomento Rural contou com o contributo, entre outros, do jovem Magalhães: "Tenho de fazer o inquérito agrícola aqui no Concelho da Maia. Assim mo participou o Oliveira Martins (Carta de Luís de Magalhães a Rita de Miranda de Magalhães, de 6 de Maio de 1887, BNL, Espólio de Luís de Magalhães, E2/cx. 36). 
entusiasmado, procurou arregimentar novos fiéis para a causa reformadora, como Jaime de Magalhães Lima, outro crente no "oliveirismo" que não deixará de avisar o amigo contra os perigos da política ${ }^{(31)}$. O seu proselitismo em relação às ideias sociais e económicas do historiador tornava-se cada vez mais evidente, defendendo que a execução do projecto económico da "Vida Nova" representava a possibilidade de Portugal se tornar "naquele país essencialmente agrícola que pretendemos ser, vivendo da gleba nacional, sem precisarmos de pedir a estranhos o pão de cada dia e tantos outros géneros que ela, mais densamente povoada, mais amplamente arroteada e irrigada, mais rendosamente cultivada, nos podia dar"(32).

A "Vida Nova" acabaria por não levar ao poder Oliveira Martins. A morte do velho líder progressista Anselmo Braamcamp, a 13 de Novembro de 1885, deixaria o Partido enredado numa teia de intrigas partidárias entre as facções do Norte, lideradas por Barros Gomes, e as de Lisboa, chefiadas por Mariano de Carvalho e Emídio Navarro ${ }^{(33)}$. O novo líder partidário, José Luciano de Castro, mostrava-se incapaz de se impor aos manejos conspirativos dos seus próceres directos, em particular a actividade subversiva dos "marechais" lisboetas. No retrato que Luís de Magalhães traçou do dirigente progressista, além de o responsabilizar pelo fracasso do movimento ${ }^{(34)}$, ecoam juízos pouco abonatórios

(31) Cf. Carta de Jaime de Magalhães Lima a Luís de Magalhães, s.d., BNL, Espólio de Luís de Magalhães, E2/cx.3/doc. 739.

(32) "Prefácio", in Oliveira Martins, ob. cit., p. XLI. Sublinhado no original.

${ }^{(33)}$ Cf. F. A. Oliveira Martins, ob. cit., p. 72 ss. Para Luís de Magalhães foi a morte de Braamcamp a responsável pelo insucesso da "cruzada nacional" de Oliveira Martins: "Braamcamp era uma alma forte, d'aço puro, n'um corpo frágil com um vime. A sua já longa vida política constituía um vivo exemplo de isenção, de patriotismo, de coerência, de firmeza moral. Para o liberalismo democrático [...] trouxera as suas qualidades de homem de raça, aquelas que devem ser o timbre da aristocracia: o ponto de honra, a dignidade altiva, $a$ independência de carácter, a severa fidelidade aos princípios ("Prefácio", in Oliveira Martins, ob. cit., pp. XLV-XLVI).

${ }^{(34)}$ Sobre a não inclusão de Oliveira Martins no governo progressista, dirá no seu Diário: "Nisto se vê como o José Luciano comprometeu logo ao princípio os antigos planos de Braamcamp. Se fosse outro homem teria dito ao rei que aceitava a missão de formar gabinete, mas reservando-se a ampla liberdade de escolher os homens com quem havia de servir. E assim ou imporia ao rei um ministério 
da sua índole política: "José Luciano de Castro Corte Real era honesto, era leal, tinha boas intenções, levava muito a sério o seu papel político, trabalhando rijamente; mas não tinha força. Era indiscreto e voltava-se com extrema facilidade. Sobre isto era medroso e tinha o vício entranhado da politiquice: amava o poder pelo poder"(35).

Para esta hostilidade a Luciano de Castro, não comungada pelo seu mestre ${ }^{(36)}$, muito contribuíra o fracasso da candidatura de Luís de Magalhães nas eleições gerais de 6 de Março de 1887. O chefe do Partido Progressista não conseguira impor a sua candidatura aos interesses partidários locais, comprovando-se, deste modo, que nem sempre o poder central tinha a capacidade de subjugar as aspirações do "campa-

de gente decidida a trabalhar, a reformar e a moralizar, ou o deixaria a descoberto, provando a incompatibilidade entre a coroa e o país. Ele, porém, desorientado com a sua própria importância, transtornado pela perspectiva de ser presidente do conselho de ministros, com a sua leviandade e precipitação habituais, curvou a cabeça às indicações do rei, aceitou tudo, subscreveu tudo e arranjou um gabinete retalhado desde a nascença por antagonismos insolúveis. A tábua de salvação duma situação progressista ajuizada e forte - perdia-se também. Nisto se via pela primeira vez a falta que o Braamcamp fez ao seu partido" (transcrito por A. Álvaro Dória, ob. cit., pp. 100-101).

${ }^{(35)}$ Citado por F. A. Oliveira Martins, ob. cit., p. 82. Anos mais tarde, no já citado prefácio aos Perfis de Oliveira Martins, manterá a análise do seu carácter "mais maleável, menos flexível de vontade, acomodando-se às circunstâncias n'um dúctil e transigente oportunismo (p. XLVI). Em 1906, quando se colocou a possibilidade de uma fusão entre o Partido Progressista e o Partido Regenerador - Liberal, Magalhães não escondeu a hostilidade para com o chefe progressista e tudo o que ele representava: "uma fusão - e, sobretudo, uma fusão em que, directa ou indirectamente, na realidade com uma simples aparência, o José Luciano tivesse o menor vislumbre de autoridade, de predomínio, [...] no partido assim criado - era coisa com que de forma alguma poderia concordar. Não posso aceitar como chefe, como superior hierárquico, pessoa a quem não reconheço a suprema autoridade do carácter. E do José Luciano penso tão mal e tão mal tenho dito, sem reservas de espécie alguma, que aceitar a sua influência, só que seja, no grupo em que me encontro, seria coisa para me ter a mim próprio em menor consideração e estima." (Carta de Luís de Magalhães a João Franco, de 1 de Abril de 1906, BNL, Espólio de Luis de Magalhães, E2/cx36).

(36) Cf. Carta de Oliveira Martins a José Luciano de Castro, in Correspondência de J. P. Oliveira Martins, Lisboa, Parceria António Maria Pereira, 1926, pp. 103-105. 
nário"(37). Com efeito, Luciano de Castro comprometera-se com Oliveira Martins a manobrar as estruturas partidárias da província no sentido de fazer eleger Luís de Magalhães pelos círculos de Penafiel ou Santo Tirso, embora reconhecesse que o prestígio dos caciques progressistas constituía forte entrave às suas pretensões ${ }^{(38)}$.

No quadro das intrigas partidárias, a eleição de discípulos fiéis a Oliveira Martins revelava-se crucial para a estratégia montada, na medida em que este necessitava de povoar a câmara legislativa com os seus acólitos mais fiéis, com vista a conferir maior visibilidade e a garantir apoios ao seu credo político. Impossibilitado de reformar a partir da cúpula governativa, Martins ambicionava determinar o sentido das reformas por via legislativa. Jaime de Magalhães Lima, também ele candidato por Aveiro, reconhecia a importância estratégica da eleição de Magalhães: "Estimo que sejas eleito e, sem lisonja, dentre os nossos és aquele que pode prestar ao Mestre melhores serviços. A tua eleição era quase indispensável"(39). Na correspondência entre José Luciano de Castro e Oliveira Martins, a que já fizemos referência, é bem evidente todo o esforço que o historiador colocou na eleição do seu delfim.

O insucesso político da contenda terá irritado Luís de Magalhães, agastado com um processo que resultava da interferência dos tradicionais processos eleitorais, em que as candidaturas se jogavam em negociatas de bastidor, ao sabor das influências dos caciques locais ${ }^{(40)}$.

(37) O testemunho de Manuel da Silva Gaio, amigo do candidato e "crente" da "Vida Nova", é significativo: "Eu não conheço homem tão pulha, tão reconhecidamente patife como o José Luciano. A sua breve travessia na política tem deixado uma esteira de indignações e despeitos justificados. A história da tua candidatura é infame" (Carta de 14 de Julho de 1887, Espólio de Luís de Magalhães, E2/cx. 4/doc. 950). Sobre o processo de designação de candidatos nas eleições oitocentistas, veja-se Pedro Tavares de Almeida, Eleições e Caciquismo no Portugal Oitocentista [1868-1890], Lisboa, Difel, 1991, pp. 70-74.

(38) Cf. José Luciano de Castro, Correspondência Política, 1858-1911 [ed. de Fernando Moreira], Lisboa, ICS/Quetzal, 1998, pp. 231-234.

${ }^{(39)}$ Carta de Jaime de Magalhães Lima a Luís de Magalhães, de 8 de Fevereiro de 1887, BNL, Espólio de Luís de Magalhães, E2/cx. 3/doc. 747.

(40) "Ainda bem que tiveste uma boa lição de política eleitoral. Precisavas muito dela e por isso mesmo que te irritas e desesperas, o que é sinal de virgindade" (Carta de Jaime de Magalhães Lima a Luís de Magalhães, de 15 de Março de 1887, Espólio de Luís de Magalhães, E2/cx. 3/doc. 748). 
Para Luís de Magalhães, como para tantos outros jovens saídos dos bancos da Universidade, a Câmara de Deputados constituía a porta de entrada no elitista sistema político, controlado por uma restrita oligarquia política reunida em torno dos partidos dinásticos. $\mathrm{O}$ desencanto e a desilusão deste primeiro insucesso eram, por isso, naturais. Mas a sua reaç̧ão será melhor compreendida se enquadrarmos a sua ambição política na natureza do seu idealismo poético. Isto é, comungando dos desígnios messiânicos do seu mestre Oliveira Martins, Luís de Magalhães apresentava-se como candidato a político morigerador, para quem a actividade política só podia ser concebida como resultado do cumprimento de um "dever moral"(41).

3. A impossibilidade reformista do movimento da "Vida Nova", fruto das manigâncias partidárias no seio do progressismo, empurrou Oliveira Martins e os seus amigos para o cesarismo de influência germânica, que no plano teórico se encontrava já devidamente fundamentado na sua História da República Romana ${ }^{(42)}$. A teoria do engrandecimento do poder

(41) Na correspondência que consultámos no Espólio de Luís de Magalhães proliferam as referências que atestam as qualidades morais do filho de José Estêvão. Para Guerra Junqueiro, Magalhães era "o único homem [...] capaz de antepor o mínimo dever ao máximo interesse" (E2/cx. 1/doc. 89 - sublinhado no original); Jaime de Magalhães Lima afirmava: "Sinto que começas a ter na minha vida moral uma influência grande [...] não tanto pela amizade e pelo conselho como por uma outra força superior a todas as demais - o exemplo (E2/cx. 3/doc. 777). O próprio se assumia como "fanático da consciência": "Mas, quando das coisas da razão passo para as coisas superiores da consciência, o seu céptico [...] torna-se num crente, num grande crente quase num fanático. $\mathrm{E}$, se lhe faz espécie que eu prescinda da razão como esteio moral, dir-lhe-ei que eu creio na moral instintiva, uma espécie de moral imanente no homem" (in Lopes d'Oliveira, ... E Mesmo Contra a Maré, Lisboa, 1945, pp. 365-368).

(42) Mostrando conhecer bem o espírito e as ideias do seu amigo, Magalhães afirmou no seu Prefácio aos Perfis, largamente citado, que foi em torno da figura de Júlio César, construída na sua História da República Romana, que o historiador estruturou as bases reformistas em que assentará o seu cesarismo. Foi em César que Martins "viu o tipo do homem de acção que, no meio da crise d'uma sociedade desnorteada pelo espírito de facção e perdida toda aquela energia colectiva que torna as nações senhoras e guias dos seus próprios destinos, sabendo-se apoiar numa força efectiva, a salva reorganizando-a politicamente em normas e fórmulas pelo seu pensamento criadas ou adaptadas às circunstâncias peculiares da nação e da sociedade a que se aplicam" (p. XX). Os abusos na utilização da 
real - o rei reina e governa - começou a ser divulgada na imprensa, com destaque para O Repórter, dirigido por Oliveira Martins, e o Tempo, de Carlos Lobo d'Ávila; e mais tarde na Revista de Portugal (1889), dirigida por Eça de Queirós e que Luís de Magalhães terá oportunidade de secretariar a partir de 1891. Para sintetizar, diremos apenas que em face do fracasso da acção parlamentar, Oliveira Martins reconhecia que as reformas que evitariam a catástrofe económica e financeira exigiam uma maior intervenção do poder moderador, à revelia dos deputados e dos senhores pares do reino. O cesarismo, como ficou então conhecido, ancorava os seus propósitos nas ideias antiparlamentares de uma elite de intelectuais, conhecida por "vencidos da vida", e que constituía a sua "inspiração governativa"(43).

Perto de 1889 , com o rei D. Luís gravemente enfermo, as esperança desta elite recaíam no príncipe $\mathrm{D}$. Carlos, que a si mesmo se rotulava de "vencido suplente". As expectativas em torno do novo rei, como se de um novo messias se tratasse, perfilhadas em alguns sectores da sociedade portuguesa, deixou-as o herdeiro de José Estêvão no seu Diário: "Que acontecerá com a morte do rei? Que fará o filho? Era preciso que nesse momento o país encontrasse um rei patriota à $\mathrm{D}$. Pedro V ou à Imperador do Brasil, pois, sem um monarca animado deste espírito, todas as empresas de regeneração política, empreendidas por via do prestígio de força da monarquia, falharão sempre sem remédio"(44). Por esta altura, D. Carlos cultivava no elitismo dos "vencidos" o ideal intervencionista, hostil aos partidos e ao parlamento, que estes disseminavam pelos órgãos da imprensa. Ganha assim especial significado a publicação de um artigo de Luís de Magalhães no jornal dirigido por Oliveira Martins, sob o

analogia entre Roma e o Portugal coevo serão criticados por Silva Cordeiro: "Com Oliveira Martins chega-se ao cúmulo de não se compreender uma situação, um período histórico, uma instituição, um carácter, individual ou colectivo, senão através do prisma clássico de Roma, identifica-se o que as mais das vezes não passa de remotamente análogo" ) A Crise em Seus Aspectos Morais, $2^{a}$ ed., Lisboa, Edições Cosmos, p. 130).

${ }^{(43)}$ Luís de Magalhães, ob. cit., p. XX. Sobre as ligações dos "vencidos da vida" com as teses de reforço do poder real veja-se F. A. Oliveira Martins, $D$. Carlos e os Vencidos da Vida, $2^{\mathrm{a}}$ ed., Lisboa, Parceria António Maria Pereira, 1942 e Oliveira Martins e os seus Contemporâneos, Lisboa, Guimarães Editores, p. 65 ss.

${ }^{(44)}$ Citado por F. A. Oliveira Martins, O Socialismo na Monarquia, p. 217. 
título "Feudalismo Eleitoral", pois terá merecido uma referência encomiástica do futuro monarca, por ele revelada ao historiador: "Dê um abraço ao Luís de Magalhães pelo seu artigo no 'Repórter'"(45).

$\mathrm{O}$ tom cordial e intimista em que o príncipe formula o elogio deixa perceber que ambos se conheciam pessoalmente. Não se estranha o facto, se pensarmos que Luís de Magalhães frequentava ocasionalmente as tertúlias gastronómicas dos "vencidos" e estava ligado por laços de amizade a algumas das altas individualidades que frequentavam o Paço, em especial Bernardo Pindela ${ }^{(46)}$. Mas que méritos encontrara D. Carlos no plumitivo escrito?

Em "Feudalismo Eleitoral", tal como o título sugere, Magalhães produziu uma curta mas incisiva reflexão crítica sobre o sistema político liberal, refutando os mecanismos eleitorais que o suportavam. Nas suas palavras, a concepção do sistema eleitoral resultava da exacerbada aplicação do doutrinarismo liberal num país que para ele não estava preparado. A mácula do sistema representativo encontrava-se na "desproporção entre a importância dos direitos políticos concedidos a um colégio eleitoral muito vasto, e a capacidade, demasiado restrita, desse mesmo colégio"(47). Isto é, Luís de Magalhães apontava ao liberalismo a impossibilidade de colocar em acção a teoria do sufrágio universal, que na prática era restritivo, num país apático e sem formação cívica ${ }^{(48)}$, de que resultava um sistema que beneficiava apenas as oligarquias dominantes, políticas e económicas, e os caciques locais ${ }^{(49)}$. A doutrina

(45) Idem, ibidem, p. 231.

(46) Sobre Bernardo Pindela e a reconstituição do ambiente mental em que decorreram os acontecimentos referidos, veja-se Amadeu Carvalho Homem, O Primeiro Conde de Arnoso e o seu Tempo, V. N. de Famalicão, Câmara de V. N. de Famalicão, 1998.

(47) O Repórter, I ano, nº 83, 24 Mar. 1888, p. 1.

(48) "Uma ou duas lições destas bastarão para convencer os mais fanáticos apóstolos do sufrágio universal da inanidade prática da sua panaceia. Eles verão quanta inércia, quanta passividade, há no fundo dessas massas, que imaginaram ardendo em desejos de se governarem a si próprias. [...] Reconhecerão enfim que, na maioria dos eleitores, o móbil que os leva à urna, não é a consciência dos seus deveres de cidadãos - mas um puro caso de interesse e, na menos imoral das hipóteses, um motivo de dedicação pessoal ou de condescendente favor" (ibidem).

${ }^{(49)}$ Sobre o funcionamento do sistema político e eleitoral do século XIX, veja-se Pedro Tavares de Almeida, ob. cit., passim. 
do sufrágio universal surgia assim como a "panaceia" que escondia um verdadeiro "feudalismo eleitoral", de que resultava a "desordem financeira, a depauperação económica [e a] corrupção política"(50).

Mas o verdadeiro interesse do artigo reside no facto de este reforçar as teses martinianas sobre o fortalecimento do poder real. Sempre atento às lições historiográficas do seu mestre, a propósito da valorização da Idade Média portuguesa, Magalhães propugnava a união entre a coroa e o povo, "entre o poder monárquico e os elementos comunais", contra os interesses da "oligarquia feudal". A intervenção do monarca na política será sustentada, em Luís de Magalhães, por critérios exclusivamente morais. O poder moderador deveria afirmar-se como uma espécie de sustentáculo dos interesses do povo face às oligarquias dominantes, uma vez que o país se encontrava desprovido de uma opinião pública forte, sem a "energia precisa" para se impor "à minoria politicante". Em conformidade, aplaudia a intervenção régia "sempre que ela se inspire num pensamento de patriotismo, de amor pelo povo, de interesse pelo bem público - cuja guarda lhe está confiada não só pela constituição, o que é pouco, mas pelos grandes e nobilíssimos deveres morais inerentes ao seu cargo"(51).

Convicto da inevitabilidade da chegada ao poder dos "vencidos da vida", sob os auspícios do novo monarca, e sustentado por um pensamento orgânico, que reverte do seu positivismo cultivado em Coimbra, o jovem ideólogo concebe um conciso programa em que preconiza a intervenção decidida de "um governo forte" controlado por um partido de elite: "Venha enfim um partido que tome por programa a organização do Estado, fazendo dele um regulador consciente das forças inconscientes da nação, um gânglio coordenador dos movimentos do organismo social, espécie de cérebro político que lhe dirija, estimule e harmonize a acção de todos os seus membros" ${ }^{\prime(52)}$.

A que partido se refere Luís de Magalhães? A um novo partido? $\mathrm{Na}$ realidade, a questão ganha relevância se a equacionarmos em função da possibilidade, na época tão discutida entre a sociedade lisboeta, de em torno dos "vencidos da vida" se forjar um novo partido. Ainda que

\footnotetext{
(50) O Repórter, I ano, nº 83, 24 Mar. 1888, p. 1.

(51) "Notas Políticas - Doutrinas e Factos", Tarde, n 2872, 30 Jun. 1897, p. 1.

${ }^{(52)} O$ Repórter, I ano, nº 83, 24 Mar. 1888, p. 1.
} 
tal intenção tenha sido desmentida por alguns dos intervenientes ${ }^{(53)}$, é quase certo, contudo, que este grémio elitista não se limitava às tertúlias gastronómicas e intelectuais. Luís de Magalhães que, como já se afirmou, participou em alguns dos ágapes, conviveu de perto com tão conspícuas individualidades ${ }^{(54)}$. Entre as actividades já referenciadas, este conta que os "vencidos" se "juntavam à noite na redacção do Tempo que Carlos Lobo d'Ávila dirigia, faziam política ou flirtavam um pouco com ela"(55).

$O$ "vencidismo" tem sido conotado com as onze personalidades que as objectivas fotográficas fixaram para a posteridade ${ }^{(56)}$, mas não erraremos muito afirmando que tal movimento constituía o reflexo mais visível da atitude política e cultural de um elitista mas significativo sector da sociedade. Ainda que resumido a uma plêiade de intelectuais e notáveis políticos e proprietários agrícolas, o espírito dos "vencidos" encontrava-se disseminado em homens como Luís de Magalhães, Jaime de Magalhães Lima, Manuel da Silva Gaio ou Alberto Sampaio(57). Todos comungavam com o diagnóstico decadentista da vida política nacional, convergindo na imperiosa necessidade de reformar as instituições. Em suma, todos exigiam uma "Vida Nova" para Portugal.

Para Luís de Magalhães, a formação de uma nova agremiação partidária, organizada em torno do espírito regenerador do "vencidismo", constituía uma aspiração e uma certeza num futuro não muito longínquo. O credo reformista e morigerante propugnado nos meios afectos a Oliveira Martins constituía o fermento para o novo partido que agruparia "certas afinidades de pensamento e uma identidade de vistas superiores [que]

\footnotetext{
${ }^{(53)}$ Cf. Manuel da Silva Gaio, Os Vencidos da Vida, Coimbra, Imprensa da Universidade, 1931.

(54) "De todos eles tive a ventura de ser amigo mais ou menos íntimo. O grande espírito de alguns deles iluminou o meu. Conheci-os na hora culminante das suas vidas, na plenitude do seu talento ou na máxima afirmação do seu carácter. Gozei o convívio encantador dessa ilustre companhia, em que se agremiaram algumas das mais ilustres figuras contemporâneas" (Correio da Manhã, III ano, $\mathrm{n}^{\circ} 847,11$ Set. 1923, p. 1 ).

(55) Ibidem.

(56) São elas Oliveira Martins, Eça de Queirós, António Cândido, Carlos Lobo d'Ávila, Ramalho de Ortigão, Conde de Sabugosa, Conde de Ficalho, Conde de Arnoso, Carlos Lima Mayer, Marquês de Soveral e Guerra Junqueiro.

${ }^{(57)} \mathrm{Cf}$. a inúmera correspondência que trocaram com Luís de Magalhães e que se encontra no valioso espólio deste último, depositado na Biblioteca Nacional.
} 
ligam uma elite de homens de talento". O que impedia a sua organização partidária? Impedia-os o facto de se encontrarem "separados contudo pelos acasos da vida pública e pela impossibilidade de se organizar de momento este caos amorfo em que se agitam [...] as ideias, os interesses, os sucessos, as individualidades"(58). Isto prova que Magalhães tinha plena consciência dos inúmeros obstáculos que obscureciam o surgimento de um novo partido político. Mas significa a afirmação de uma nova sensibilidade que não se revia nos partidos dinásticos, descontente com a sua política de conservação e imobilismo.

4. Os fracassos da sua primeira aventura política deixaram marcas profundas no herdeiro de José Estêvão, que procurou refúgio na Quinta do Mosteiro ${ }^{(59)}$, o seu Vale de Lobos. Aí, em torno da sua família, irá canalizar todos os esforços para aquelas que seriam, a partir desse momento, as suas actividades predilectas: a agricultura e a poesia ${ }^{(60)}$. Com apenas vinte e nove anos, o espírito de Luís de Magalhães navegava agora ao sabor dos seus fracassos políticos, deixando-se conduzir, lentamente, a um fundo sentimento pessimista, que o tornava descrente nas possibilidades de regeneração do país. Equacionava já a possibilidade de não voltar à ribalta da política, canalizando por inteiro as suas energias intelectuais para as actividades literárias. Se Oliveira Martins passeava

(58) Luís de Magalhães, “O baralho político", O Repórter, I ano, n 32, 1 Fev. 1888, p. 1. Para Luís de Magalhães, a nova agremiação partidária deveria pressupor "uma constituição política orgânica deduzida logicamente das nossas tradições histórico-sociais e não modelada apenas por vagas abstracções jurídicas" (Ibidem).

(59) Situada em Moreira da Maia, concelho da Maia, fora comprada por sua mãe, D. Rita Miranda de Magalhães em Fevereiro de 1874, e pertencera em tempos aos frades crúzios. Depois do seu casamento com D. Maria da Conceição de Lemos Pereira de Lacerda, em 1884, Luís de Magalhães passará a residir em Campanhã, na Quinta do Barroco e mais tarde na rua do Brayner. Só no Outono de 1886 fixará residência na Quinta do Mosteiro que será o seu refúgio. A Quinta do Mosteiro será descrita por Eça de Queirós, seu frequentador, na Correspondência de Fradique Mendes: "pertence a um amigo meu, que é, como Virgílio, poeta e lavrador, e canta piedosamente as origens heróicas de Portugal enquanto amanha os seus campos e engorda os seus gados" ( $6^{\text {a }}$ ed., Porto, 1921, p. 220).

${ }^{(60)}$ A fundação de um jornal, com Jaime de Magalhães Lima, falhou no início de 1888, mas desconhecem-se os motivos. Cf. Carta de Jaime de Magalhães Lima a Luís de Magalhães, de 9 de Março de 1888, BNL, Espólio de Luís de Magalhães, E2/cx. 3/doc. 758 . 
nas tertúlias lisboetas do "vencidismo" a sua frustração, o seu discípulo encontrava na familia e em "Virgílio" o alento e o amparo contra os desencantos da política ${ }^{(61)}$.

O sossego do campo, porém, seria de curta duração. Como um furacão político, a terrível convulsão do ultimato inglês, de 11 de Janeiro de 1890, iria despertar $\mathrm{o}$ animal político, arrancando abruptamente o poeta à lira e o lavrador ao arado. Ao clima de histerismo antibritânico que se seguiu ao ultimatum ${ }^{(62)}$ não seria indiferente o patriotismo ferido de Luís de Magalhães, que arrastará Antero de Quental para as actividades da Liga Patriótica do Norte ${ }^{(63)}$. Na realidade, o golpe desferido pelos ingleses renovava no espírito poético de Magalhães a crença numa nova redenção messiânica, em que o poeta das Odes Modernas se afirmava como o elemento moral congregador ${ }^{(64)}$. Como ele recordará mais tarde, a questão inglesa insuflara-lhe a esperança no renascimento do país "não pela acção dum partido, mas pela miraculosa ressurreição do sentimento colectivo, pela paixão cívica, pelos ímpetos dum patriotismo heróico, despertado pela chicotada humilhante do estrangeiro"(65). Para a Liga Patriótica, Magalhães reservava a acção enérgica que convocaria o espírito heróico dos portugueses para o combate à decadência e para a construção da "futura vida nova". Nesse apelo ganhou particular relevo a simbologia

(61) Jaime de Magalhães Lima procurará demovê-lo: "Mas de que não posso dar-te os parabéns é dos protestos de abstenção política e de consagração exclusiva às letras" (Carta de 6 de Abril de 1889, BNL, Espólio de Luís de Magalhães, E2/cx. 3/doc. 870).

${ }^{(62)}$ Sobre a reacção do país ao ultimato veja-se Amadeu Carvalho Homem, "O ‘Ultimatum' inglês de 1890 e a opinião pública", Revista de História das Ideias, Coimbra, vol. 14, 1992.

${ }^{(63)}$ Cf. Luís de Magalhães, "A Vida de Antero", In Memoriam, Porto, Matheu Lugan, 1896.

(64) "O nome de Antero de Quental à frente da Liga Patriótica do Norte - é a máxima garantia da empresa iniciada. Ninguém, como este homem excepcional, concentra em si faculdades e predicados, para dirigir, personificar até, um movimento desta ordem" ( $A$ Província, VI ano, $\mathrm{n}^{\circ} 30,6 \mathrm{Fev}$. 1890). Sobre a reacção de ambos e as actividades da Junta Patriótica do Norte vejam-se os artigos publicados em A Província entre Janeiro e Fevereiro de 1890. Para uma leitura interpretativa dos mesmos, veja-se Maria Teresa Pinto Coelho, Apocalipse e Regeneração: o Ultimatum e a mitologia da pátria na literatura finissecular (policopiado), Oxford, 1994, p. 120 e ss.

${ }^{(65)}$ Tarde, XI ano, $\mathrm{n}^{\circ}$ 3020, 22 Dez. 1897, p. 1. 
da pátria e da antiga grandeza nacional: "A missão iminente da Liga será pois, quanto a nós, determinar no país uma enérgica acção moral que nos faça erguer do marasmo em que caíramos; será estimular por todos os modos o sentimento pátrio, o orgulho da raça, o amor das tradições, a abnegação cívica, a elevação de todos os corações pela fé de novos destinos e pela esperança duma vida nova. A missão capital da Liga será restaurar esta nacionalidade perdida, avivando as energias cansadas do seu carácter histórico e adaptando-o às condições do presente momento social" (66).

A excessiva ingenuidade desta iniciativa, mais emotiva do que racional, a evocar a sensibilidade poética ou apaixonada dos seus intervenientes, a que se juntara o idealismo juvenil dos estudantes da academia do Porto, depressa a condenou ao fracasso. Em vez da tão esperada renovação, o ultimato inglês ficará para a história como o início da derrocada do regime monárquico em Portugal. No imediato, significou o agravamento da situação económica e financeira e açodou o processo de desorganização dos partidos rotativos, afastados do poder entre Outubro de 1890 e Fevereiro de 1893. Como consumou a afirmação do republicanismo na sua vertente revolucionária que culminaria no golpe, ainda que incipiente, de 31 de Janeiro de $1891^{(67)}$.

A 13 de Outubro de 1890 seria empossado o governo extrapartidário do general João Crisóstomo, numa tentativa de acalmar os ânimos agitados pela assinatura do tratado entre Portugal e Inglaterra, em Agosto desse ano. António Cândido e António Enes eram os nomes fortes do governo e ambos dissidentes do Partido Progressista e apoiantes da "vida nova" de Oliveira Martins. Não se estranha, pois, que António Cândido, ministro do reino, convidasse Luís de Magalhães, através do historiador, para ocupar o cargo de governador civil: "O António Cândido acaba de conversar comigo dizendo-me que gostaria muito que $\mathrm{V}$. o coadjuvasse neste momento grave e difícil. Lembrou-se de lhe oferecer um dos

(66) "A Liga Patriótica", A Província, VI ano, n² 25, 31 Jan. 1890, p. 1.

${ }^{(67)}$ Ainda que o ultimato demonstrasse a incapacidade das chefias do Partido Republicano para aproveitar o clima de agitação que se vivia, o que em parte explicará o fracasso do 31 de Janeiro, este teve o mérito de insuflar nas hostes republicanas um espírito mais revolucionário. Cf. Amadeu Carvalho Homem, "Conciliação e confronto no discurso republicano [1870-1890]", Revista de História das Ideias, Coimbra, vol. 7, p. 308. 
governos civis vagos [...] mas não quis fazê-lo por não saber como seria recebido o convite. [...] Como este ficou em aberto, eu escrevo-lhe a $V$. fazendo-lho em meu nome ${ }^{\prime \prime(68)}$. Um convite que representava a necessidade do governo em arrebanhar gente nova, recrutada fora dos arraiais do rotativismo, abrindo assim as portas de acesso ao poder a novos quadros políticos. Em última análise, os governos extrapartidários significaram o acesso aos bancos do poder de alguns dos corifeus do reformismo liberal, oriundos da frente antiparlamentar e defensora do engrandecimento do poder real.

Luís de Magalhães responderá negativamente ao convite em missiva dirigida ao próprio António Cândido, alegando "ignorância das coisas administrativas e no desconhecimento completo dos homens com quem teria de lidar ${ }^{\prime \prime(69)}$. Como explicar esta mudança de atitude face às ambições políticas expostas anteriormente? O agravamento das tensões em torno da governação monárquica e o amadurecimento da sua visão política, associados ao seu pessimismo crescente poderão explicar a recusa. Mas esta releva igualmente do seu conhecimento sobre a praxis política institucionalizada, em particular o reconhecimento da especificidade do cargo para que fora convidado: "Com uma situação partidária um governador civil é apenas um intermediário entre o governo e os influentes locais que são o seu ponto de apoio. Mas numa situação sem cor política, e numa terra onde se não tem relações pessoais [o convite de Martins falava em Viana, Bragança e Portalegre] nem correligionários e, nem ao menos, com amigos, que poderia fazer um pobre homem a quem falta de resto a indispensável prática da vida política?"(70). Convirá não esquecer que o cargo de governador civil constituía peça fundamental na estratégia política e eleitoral dos governos liberais daquela época. Era o governador civil quem controlava o aparelho eleitoral e fiscalizava os actos eleitorais, quem coordenava o processo de angariação de votos e, em última análise, quem servia de intermediário entre os caciques

${ }^{(68)}$ Carta de Oliveira Martins a Luís de Magalhães, s.d., BNL, Espólio de Luís de Magalhães, E2/cx. 1/doc. 159.

${ }^{(69)}$ Carta de Luís de Magalhães a António Cândido, s.d., BNL, Espólio de Luís de Magalhães, E2/cx. 36.

${ }^{(70)}$ Carta de Luís de Magalhães a António Cândido, s.d., BNL, Espólio de Luís de Magalhães, E2/cx. 36. 
locais e a administração central ${ }^{(71)}$. Como reconhece o próprio Magalhães, sem contactos pessoais ou partidários e conhecimentos firmes no terreno, a aç̧ão do governador civil teria de debater-se com fortes obstáculos, de que resultaria a inoperância e inocuidade da função.

Ausente da actividade política, Luís de Magalhães acabará confrontado com nova faceta - a de analista político. Eça de Queirós juntara os seus amigos de tertúlias literárias num projecto arrojado, que procurava conciliar objectivos políticos discretamente assumidos com uma feição literária objectivamente comprometida com o espírito de intervenção cultural que o seu mentor preconizava. Para a Revista de Portugal, Luís de Magalhães apresenta-se como uma espécie de analista dos factos políticos nacionais mais relevantes, dando assim cumprimento aos desígnios do seu director e amigo(72). Com o significativo título de "Revista de Política Interna", o político cedia o lugar ao crítico, penetrante e incisivo na forma como abordava as questões de actualidade política. Desde o ultimato inglês, passando pela tentativa revolucionária de 31 de Janeiro, com incursões explicativas sobre o republicanismo, até às questões ibérica e financeira, a pena arguta de Magalhães decompunha os acontecimentos do seu tempo, onde identificava sinais evidentes da "marcha patológica dos complexos males que vão lentamente minando, decompondo, e até ameaçando de morte, o caduco organismo nacional"(73).

Em jeito de remate conclusivo, o analista considerava que o país se consumia em conflitos internos cuja deflagração os governos parlamentares não conseguiriam impedir. Da solução por este urdida despontava a imperiosa necessidade de se constituir "um governo forte, com energia e com decisão, com autoridade e prestígio, que domine a anarquia reinante, liquide de pronto as questões pendentes e inicie com novos processos de administração essa messiânica vida nova"(74). A afirmação do reforço do poder executivo, como instrumento político, inscrevia-se

(71) Cf. Pedro Tavares de Almeida, ob. cit., pp. 119-121.

(72) "Falta-lhe porém a secção essencial: a Revista da Política Interna. Muitas vezes me tenho perguntado a mim mesmo quem o poderia fazer com suficiente independência, critério, ousadia, estilo e ciência. E descobri há dias, de repente, que só V. possui juntas essas qualidades" (carta de Eça de Queirós a Luís de Magalhães, 23 de Janeiro de 1891, BNL, Espólio de Luís de Magalhães, E2/cx.1/ doc. 14).

(73) Revista de Portugal, vol. 3, p. 479.

(74) Ibidem, vol. 3, p. 624. 
no ambiente antiparlamentar que grassava nos meios próximos dos sectores excluídos da militância partidária. Traduzia uma necessidade urgente, face ao avanço rápido do espírito revolucionário, de encontrar dentro da monarquia os mecanismos reformadores que evitassem o deflagrar da revolução ${ }^{(75)}$.

A prova que Luís de Magalhães não se encontraria isolado na leitura que fazia da realidade nacional, bem como das soluções transitórias que aventava, encontramo-la nos significativos manifestos de simpatia com que eram recebidas as suas "Revistas de Política Interna". Eça de Queirós foi um dos que não lhe recusou elogios ${ }^{(76)}$. O monarca, por sua vez, contava-se entre os seus mais assíduos e efusivos leitores ${ }^{(77)}$.

5. Em 1892 a crise financeira não dava sinais de recuar e José Dias Ferreira seria chamado por D. Carlos para formar governo, após combinação com Oliveira Martins. Luís de Magalhães será de novo convidado para assumir o cargo de governador civil, em Aveiro. Se o convite não estranha, já o facto de ele partir do ministro da fazenda, e não do ministro do reino, como era tradicional, só pode significar a predominância de Oliveira Martins na formação do executivo. As suas fortes ligações ao Paço, através de alguns dos "vencidos" - Conde Arnoso, Conde de Ficalho, Conde de Sabugosa - aumentavam-lhe a consideração do monarca.

(75) "Reprimir a anarquia, restabelecer a confiança pública, pôr um travão seguro na roda dos desperdícios, fazer presidir à administração dos dinheiros do Estado a mais severa e intransigente economia e a mais insuspeita honestidade, reduzir as despesas, promover o aumento das receitas, dar um golpe na nefasta influência da burocracia, conter em respeito o egoísmo político dos partidos perante a suprema necessidade de salvação pública, corrigir todos os abusos, refrear todas as ambições ilegítimas, restabelecer o equilibrio orçamental, fomentar o desenvolvimento económico do país" (Revista de Portugal, vol. 3, p. 624). Quanto aos métodos políticos, o próprio reconhecia a cada instante as dificuldades que representava em Portugal a construção de um governo de força contra os partidos dinásticos e contra os interesses estabelecidos (Ibidem, p. 625).

(76) "As suas Revistas têm sido excelentes. Esta última sobretudo, agrada-me, consideravelmente. Conhecimento muito exacto das coisas, sentimento muito flagrante das nossas reais realidades, desassombro superior em dizer a verdade, penetração que fura para longe, forma de admirável lucidez e precisão - enfim tudo o que faz um bom e sólido estudo" (Obras de Eça de Queirós-Correspondência, Lisboa, Livros do Brasil, s.d., p. 179).

(77) Cf. ibidem, p. 182. 
Nos meios aristocráticos do Paço, Oliveira Martins continuava a ser visto como uma espécie de salvador da pátria( ${ }^{(78)}$.

$\mathrm{O}$ apelo do novo ministro da fazenda foi formulado em termos que não permitiam a recusa de Magalhães. Na carta em que Martins endereça o convite, torna-se evidente, não só a amizade e a solidariedade que une os dois homens, mas igualmente a sintonia política quanto à natureza da missão para que ambos eram chamados: "Na Segunda-feira se apresenta às câmaras o ministério José Dias em que entra este seu criado. Faltar-me-á ver somente que $\mathrm{V}$. me abandone à minha sorte, recusando-me o concurso da sua cooperação. Meu querido Luís: isto é sério e grave, nem eu entro em coisas que o não sejam. Eu, sinceramente lhe afirmo que abdiquei hoje, de mim, do meu sossego, dos meus interesses, dos meus gostos. E fiz isso, sem hesitar, nem me arrepender, porque entendo que neste momento a obrigação de todos os portugueses fazer outro tanto"(79). Oliveira Martins, como já antes António Cândido, procurava o apoio dos seus amigos para poder enfrentar os espinhosos desafios da governação. Em carta a Jaime de Magalhães Lima, em que o incita a apoiar o seu governo, a justificação será formulada em termos maniqueístas, no tom excessivamente dramático tão característico do historiador, em nome da crescente hostilidade aos partidos: "Se nos acharmos sós em campo contra a coligação dos políticos, estamos perdidos e connosco esta tentativa de restauração nacional. Quer V. o remorso de não ter cooperado, embora duvide do êxito?" ${ }^{(80)}$.

A natureza dos argumentos com que Oliveira Martins suplicava o apoio de Luís de Magalhães e de Jaime de Magalhães Lima decorre da leitura decadentista com que esta elite cultural, ligada à geração de 70 ,

(78) Em carta de 15 de Outubro de 1890 declarava-lhe o Conde de Arnoso: “Não sei e não descubro a razão, porque o não vejo dirigindo os negócios da fazenda nesta terrível crise que vamos atravessando. $O$ que sei, de sobra e com profundíssima mágoa, é que o país pagará com o ter ficado de fora o único homem que nos poderia salvar. A minha confiança em si, querido Oliveira Martins, é tal que só reputo salvável o país se puserem aos seus ombros, a pesada cruz da governação" (Correspondência de J. P. Oliveira Martins, p. 123).

(79) Carta de Oliveira Martins a Luís de Magalhães, Janeiro de 1892, BNL, Espólio de Luís de Magalhães, E2/cx.1/doc. 174.

${ }^{(80)}$ Correspondência de J. P. Oliveira Martins, pp. 182-183. Noutra carta, a Bento de Sousa Carqueja, de 16 de Janeiro de 1892, solicitará a "simpatia" do Comércio do Porto, que aquele dirigia, para o novo elenco governativo. 
interpretava o destino de Portugal. Por um lado, a inevitável articulação da ressurreição nacional com o fundo messiânico do decadentismo nacional, conferindo ao exercício do poder, haurido dos textos bíblicos, o sentido de sacrifício árduo, um "martírio", a acusar um certo desprendimento pelo poder. Como Martins lembra ao "S. Paulo da Vida Nova", assim se referiam a Magalhães alguns dos seus amigos, "não se trata de gozar o poder: trata-se de lhe sofrer o martírio. A V. posso falar assim porque sei que o compreende. Responda-me, pois, dizendo-me que me não abandona"(81). Esta sublimação da ética no exercício do poder não escondia, porém, a convicção, plenamente assumida, da improficuidade do esforço, tão ao gosto pessimista de Oliveira Martins e da geração de 70: "V. sabe de mais que o êxito é coisa indiferente para a noção de dever", sentencia ele no convite endereçado a Jaime de Magalhães Lima.

A passagem pelo governo civil de Aveiro constituiu, pois, o baptismo de Luís de Magalhães no exercício de cargos políticos. Um exercício que, para o filho de José Estêvão, preso à sua condição de proprietário agrícola, e cada vez mais pessimista quanto à evolução das coisas públicas ${ }^{(82)}$, constituirá, de facto, um verdadeiro sacrifício, do espírito e dos seus negócios, como lembra o seu amigo Alberto Sampaio: "Acabo de saber [... ] que sempre teve d'aceitar o governo civil d'Aveiro. Não é caso para parabéns, pois conheço o sacrifício que isso lhe custa"(83). A não ser motivado pela amizade pessoal e pela solidariedade, a política deixara de constituir ambição para Luís de Magalhães e representava sério entrave às suas actividades produtoras.

O sacrifício, porém, terminaria ao fim de meia dúzia de meses, enredado num confronto com José Dias a propósito das eleições do distrito $^{(84)}$. Oliveira Martins, que também saíra do ministério em ruptura com o chefe de governo, após escassos meses de exercício - de 17 de

(81) Carta de Oliveira Martins a Luís de Magalhães, de Janeiro de 1892, BNL, Espólio de Luís de Magalhães, E2/cx.1/doc. 174.

${ }^{(82)}$ Cf. Carta de Luís de Magalhães ao Conde de Arnoso, de 17 de Setembro de 1895, BNL, Espólio de Luís de Magalhães, E2/cx. 36.

(83) Carta de Alberto Sampaio a Luís de Magalhães, de 23 de abril de 1892, BNL, Espólio de Luís de Magalhães, E2/cx. 1/doc. 445.

${ }^{(84)}$ Cf. Carta de Oliveira Martins a Luís de Magalhães, 1892, BNL, Espólio de Luís de Magalhães, E2/cx.1/doc. 177. 
Janeiro a 28 de Maio - preparava-se para se candidatar pelo Porto às eleições no final de 1892. De novo instava com o amigo para que o coadjuvasse, aceitando a candidatura a deputado por Vila do Conde ${ }^{(85)}$. Desta vez, porém, nada o faria mudar de ideias. Luís de Magalhães só voltará à política em 1897, como doutrinador do jornal Tarde, quando o franquismo surgir nimbado de nova inspiração reformista.

A impotência dos desígnios regeneradores, com que se apresentaram ao país, conduzirá inexoravelmente os dois amigos aos respectivos lares, cultivando um certo misantropismo e vivendo unicamente para as letras. Luís de Magalhães decidido a finalmente dar forma ao grande poema da sua vida, $D$. Sebastião, que publicará em 1898, ao fim de vários anos de trabalho, ao mesmo tempo que empreendia a hercúlea tarefa de organizar o In Memoriam de Antero de Quental. O historiador regressava à escrita historiográfica para dar à estampa, ainda em vida, $A$ Vida de Nun'Alvares e, publicadas a título póstumo, as Cartas Peninsulares [1895] e o Príncipe Perfeito (1896). Até à sua morte, ocorrida a 24 de Agosto de 1894, Oliveira Martins dispensa a Luís de Magalhães sinais inequívocos de profunda amizade, conservando-o no seu estrito grupo de relações: "Já tinha verdadeira saudade de ver letras suas [...]. Cada vez se me faz mais restrito o número de pessoas com quem me entendo afectivamente e por isso V. que é um dos raríssimos que tem sempre um grande lugar na minha lembrança" ${ }^{\prime \prime 66)}$.

\section{Sob o signo da Pátria: cultura política em Luís de Magalhães}

1. Em 1893, Jaime de Magalhães Lima dirigia-se a Oliveira Martins nestes termos: "A verdade meu amigo é que sinceramente penso que V. foi o maior educador da nossa geração" ${ }^{\prime(87)}$. A justificação para o teor panegírico da afirmação pode vislumbrar-se numa certa esperança

${ }^{(85)}$ Carta de Oliveira Martins a Luís de Magalhães, 1892, BNL, Espólio de Luís de Magalhães, E2/cx. 1/doc. 182.

${ }^{(86)}$ Carta de Oliveira Martins a Luís de Magalhães, 1892, BNL, Espólio de Luís de Magalhães, E2/cx. 1/doc. 186.

(87) Carta de Novembro de 1893, in Correspondência de J. P. Oliveira Martins, Parceria António Maria Pereira, Lisboa, 1926, p. 238. 
messiânica nas capacidades estadísticas do historiador ${ }^{(88)}$. Não se esqueça que Oliveira Martins era aceite nos meios mais conservadores, longe das agremiações partidárias, como o inspirador do reformismo liberal. Vimos já como este pontificava em torno do elitista grupo dos "vencidos", congraçando em torno do seu nome uma verdadeira admiração.

Luís de Magalhães fez parte deste restrito grupo social e político para quem o historiador representava a derradeira esperança quanto às possibilidades objectivas de regeneração do país. No seu caso, porém, o convívio com o historiador e os ensinamentos bebidos directamente nas suas obras contribuíram decisivamente para a sua formação política e ideológica. Ora o verdadeiro significado da sua intervenção pública só será devidamente compreendido se enquadrado nos ideais propugnados pela geração de 70, com destaque para Oliveira Martins, Antero de Quental e Eça de Queirós, seus heróis, mestres e amigos. Entre estes, Martins destaca-se devido ao fulgor e ao sentido interpretativo da sua obra historiográfica, mas igualmente por via das suas ambições reformadoras da vida nacional.

O primeiro contacto de Magalhães com Oliveira Martins aconteceu, aliás, por via dos seus escritos, como o próprio virá a confessar ${ }^{(89)}$. O historiador vivia no Porto desde 1874, onde dirigia as obras de construção do troço ferroviário entre a capital nortenha e a Póvoa do Varzim e da qual se tornará director até 1888. Passado o fervor socialista, do qual publicou a Teoria do Socialismo e Portugal e o Socialismo, o labor martiniano irá centrar-se na história com livros que irão marcar intelectual e politicamente o jovem Luís de Magalhães: História da Civilização Ibérica (1879), História de Portugal (1879), Portugal Contemporâneo (1881) e História da República Romana (1885).

Magalhães encontrava-se, por essa altura, a frequentar a Universidade para onde entrara em 1877. A sua formação intelectual, como a da sua geração, será fortemente marcada pelo filosofia positivista, por influência

(88) “Quando estávamos saturados de desilusões, cansados do desregramento de toda a espécie que foi característico da primeira metade deste século, quando ansiávamos por saber, por qualquer coisa de positivo e certo que nos guiasse, V. ensinou-nos quanto se sabia, e nessa empresa, que fecundidade, que labor $e$ que elevação de pensamento" (ibidem).

(89) "Eu conhecia-o apenas pelas suas obras e por algumas cartas que trocámos quando eu publiquei os meus 'Primeiros Versos'" (Miranda de Andrade, ob. cit., p. 24). 
do professor Manuel Emídio Garcia, catedrático de Direito Pátrio e grande propagador da filosofia comtiana ${ }^{(90)}$. As suas aventuras literárias no decorrer deste período não evitaram as incursões no cientismo positivista, particularmente evidentes nas duas revistas dadas à estampa em 1880: a Revista Literária e Científica, escrita com a cumplicidade do poeta António Feijó, e Zumbidos, que contou com a conivência do seu amigo Carlos Lobo d'Ávila ${ }^{(91)}$.

Apesar da influência do positivismo, que se diluirá com o tempo, estamos convictos de que a formação intelectual de Luís de Magalhães é sobretudo devedora das interpretações historiográficas de Alexandre Herculano e de Oliveira Martins. E inscreve-se no hipercriticismo da geração de 70, no seu projecto de interrogar o sentido da aventura nacional, "a totalidade do seu ser histórico-cultural"(92). O radicalismo da sua visão cultural do país, deduzida da marginalização de Portugal em relação ao mundo "civilizado" e "moderno", conduziu a geração de 70 à formulação de um diagnóstico decadentista de Portugal e do seu povo. Para esta leitura cruel dos destinos "lusitanos" contribuíram significativamente as obras historiográficas de Oliveira Martins, que conduzirão Magalhães pelo barco da trilogia simbólica - decadentismo-sebastianismo-messianismo - com que a sua geração interpretou e ambicionou regenerar o Portugal do fim de século.

A teoria da decadência, matriz fundamental de compreensão da geração de $70^{(93)}$, emoldura o rutilante intróito da Revista Científica e Literária, publicada em Coimbra em 1880 por Luís de Magalhães e António Feijó. Aí podia ler-se que "Portugal apresenta este mórbido sintoma, triste e desolador. Sem o estímulo superior de uma mentalidade com

${ }^{(90)}$ Durante esse período escreveu "Há na sociologia fenomenalidade natural? Ideia de lei em sociologia" (in Estudo Sociológico para a Sétima Cadeira de Direito, Coimbra, Imprensa Académica, 1880, pp. 7-22), estudo onde demonstrou largo conhecimento do positivismo, citando Littré, Spencer, Stuart Mill, Comte, Teófilo Braga e Júlio de Matos. A sua tese de fim de curso será dedicada ao Casamento (1880), onde defenderá uma concepção positivista do casamento.

(91) Para uma análise do conteúdo das revistas, veja-se Miranda de Andrade, ob. cit., pp. 5-22.

(92) Eduardo Lourenço, O Labirinto da Saudade, $1^{\text {a }}$ ed., Lisboa, Gradiva, 2000, p. 90 .

(93) Veja-se António Machado Pires, A Ideia de Decadência na Geração de 70, $2^{a}$ ed., Lisboa, Vega, 1992. 
disciplina e ideal, a sociedade portuguesa tem gradualmente decaído, nestes últimos três séculos, do apogeu de uma das mais brilhantes hegemonias da história até à estagnação absoluta dos sentimentos sociais [...]. E o que mais assusta nesta decadência desgraçada é a sua lentidão [...], o seu movimento evolutivo, que parece confirmá-la irrevogavelmente. Renasceremos?"(94).

Aos vinte e um anos, aquilo que ingenuamente consentiria em ser tratado por devaneios de juventude, reverte afinal da leitura atenta dos argumentos que o ícone intelectual da época, Antero de Quental, e antes dele Herculano, utilizou no seu A Causa da Decadência dos Povos Peninsulares, e que teriam influído nas interpretações do próprio Oliveira Martins ${ }^{(95)}$. De facto, as causas da decadência nacional eram apontadas pelos jovens decadentistas ao "monarquismo jesuítico" que durante três séculos "esterilizou" ou "corrompeu" todos os esforços de regeneração(96).

Ainda sob a influência de Augusto Comte, os jovens candidatos a intelectuais consideravam que o esforço de regeneração era indissociável da qualidade do escol intelectual do país. Em conformidade, era na decadência das elites culturais, excluída a geração de 70, objecto de magna admiração em virtude da sua reacção, que devia buscar-se a explicação para o "estacionamento das civilizações". Partindo deste pressuposto, Magalhães e Feijó consideravam que a eventual "morte da nacionalidade" resultava da inaç̧ão dessa casta superior. A decadência nacional surge na Revista como corolário da "falta de actividade mental", uma vez que a prosperidade do país "está na razão directa do seu avanço científico e literário"(97). Tal como a geração que admiravam, os jovens académicos procuram contribuir para a recuperação desse "atraso demencial" do país, erguendo, refulgente, um vasto programa, uma "ideia" salvadora que libertaria Portugal dos miasmas do passado, em especial a educação religiosa, e lhe mostraria os "horizontes do futuro"(98).

(94) Revista Científica e Literária, n. ${ }^{\circ} 1$, Dez. 1880, p. 1.

${ }^{(95)}$ Cf. Fernando Catroga, "História e Ciências Sociais em Oliveira Martins", in História da História em Portugal, Sécs. XIX-XX, vol. 1, Lisboa, Temas e Debates, p. 167.

${ }^{(96)}$ Revista Científica e Literária, n. ${ }^{\circ}$ 1, Dez. 1880, p. 3.

(97) Ibidem, p. 1.

(98) "Preocuparmo-nos com o grande movimento social, que em volta de nós se opera; adquirir a consciência nítida do que somos, do que valemos e podemos valer, económica e politicamente; levantar as almas abatidas pela insuflação de 
A teoria da decadência revela-se, pois, desde muito cedo, estruturante no ideário de Luís de Magalhães, como aliás nas gerações futuras. Fruto do convívio intelectual com uma elite pensante, é sobre o decadentismo que o político assentará a lógica e os pressupostos da sua intervenção política. Vejamos, por ora, como se manifesta nos seus escritos o diagnóstico catastrofista para atendermos a seguir aos valores políticos e culturais em que sustenta a sua intervenção pública.

A censura ao liberalismo individual será para Magalhães, como para a geração de 70, a pedra angular de todo o criticismo decadentista. Segundo o seu raciocínio, a teoria liberal assentou os pressupostos da organização política e social do Estado na ideia de que bastava a proclamação universal de direitos como o sufrágio e a igualdade civil para que os povos se elevassem à máxima justiça social. Para Luís de Magalhães, porém, a "ilusão do liberalismo doutrinário", se destruiu a sociedade aristocrática do Antigo Regime e o poder absoluto dos reis, apenas deixou no seu lugar "o poder individual de cada um" ${ }^{\prime(99)}$. No fundo, o liberalismo substituíra uma sociedade desigual por outra igualmente desigual: "À ordem mais ou menos racional, substituiu-se a anarquia livre que, em vez de abrir caminho à igualdade - ideal das democracias - a abre a uma nova hierarquia, baseada na astúcia, na força e na riqueza" (100).

No individualismo liberal, Luís de Magalhães entrevia, portanto, a explicação da decadência política e social que o país atravessava, consequência das profundas injustiças que resultavam da edificação de uma nova "oligarquia dominante". Os jesuítas já não se encontravam isolados como explicação. Magalhães aprendera bem a lição do seu mestre, afirmando com Oliveira Martins que o liberalismo se limitara a perpetuar a decadência que já vinha de trás.

A realidade dos textos vem confirmar, assim, a influência da obra historiográfica de Oliveira Martins na organização do ideário de Magalhães. Os juízos severos com que sentencia o liberalismo em Portugal foram

uma ideia nobre; desbestializar o povo cretinizado por uma política exploradora e por uma catequese religiosa, grosseiramente material e fetichista: - eis algumas das resoluções heróicas, que, uma vez tomadas, poderão dar como alavancas enérgicas o primeiro impulso ao movimento que é preciso, que é indispensável suscitar no nosso país" (Revista Científica e Literária, n. ${ }^{\circ} 1$, Dez. 1880, p. 2).

${ }^{(99)}$ Luís de Magalhães, Notas e Impressões (Artes e Letras - Política e Costumes), Porto, Livraria Portuense, 1890, pp. 141-149.

${ }^{(100)}$ Idem, ibidem. 
hauridos nas leituras ávidas de conhecimento da sua formação juvenil. Ainda na Revista Científica e Literária foi possível descortinar, numa ligeira recensão crítica ao Portugal Contemporâneo, um precoce assentimento acerca da validade do diagnóstico decadentista de Martins. Na exígua nota de leitura, Luís de Magalhães conforma-se com o incisivo libelo acusatório com que a pluma do historiador desacredita a política portuguesa desde 1834, com enfoque particular para o período conhecido como "regeneração": "Vê-se que a política portuguesa é desde então para cá uma política artificial, feita por dois grupos que tiveram os seus partidários sinceramente iludidos, e que hoje apenas têm partidários sinceramente... interessados..."(101).

O Portugal Contemporâneo tem sido considerado como um livro essencialmente antiliberal, que se limita a derramar exacerbado ódio sobre o regime construído em 1834, onde apenas umas quantas figuras de proa, como Mouzinho, Passos Manuel ou Herculano, merecem a simpatia do crítico ${ }^{(102)}$. No fundo, como livro da decadência que é, acaba por apresentar o projecto liberal como o prolongamento da decadência e por isso incapaz de sufocar a crise e impedir a derrocada ${ }^{(103)}$. O fundo pessimista subjacente entendia-o Luís de Magalhães como produto de uma "visão idealista das coisas" de que resultava um agravamento do "significado moral" dos actos dos homens por um julgamento severo ${ }^{(104)}$. O que explica o tom dramático em que o livro foi escrito, a deixar perceber um final trágico, a morte da nacionalidade.

Para Luís de Magalhães, a intelecção do decadentismo e das suas consequências só podia ser intuída, porém, quando inserida na esfera da moral individual, deixando à vista a sua emanação metafísica. De facto, ao considerar que as ideias e as doutrinas "só se tornam realidades incarnando no homem" e este era um "animal inconstante e fraco", Magalhães atribuía à acção individual a verdadeira responsabilidade pela decadência social. Nessa perspectiva, as causas do decadentismo não podiam

${ }^{(101)}$ Revista Científica e Literária, $\mathrm{n}^{\circ} 2$ 2, p. 96. No mesmo artigo, Magalhães não se limita a concordar com o historiador. Em crítica incisiva e acertada, irá apontar-lhe alguns aspectos negativos resultantes de um método "extremamente sintético" de que resultou a crítica achar-se "escravizada pelo juízo do historiador que só aponta os factos comprovativos da sua opinião" (ibidem, p. 95).

${ }^{(102)}$ Cf. António Machado Pires, ob. cit., p. 199 ss.

${ }^{(103)}$ Cf. Fernando Catroga, ob. cit., p. 175.

(104) "Prefácio", in Oliveira Martins, ob. cit., p. XI. 
dissociar-se da degenerescência moral do indivíduo, agrilhoado aos impulsos naturais do seu "egoísmo instintivo", preocupado exclusivamente com a satisfação dos seus interesses particulares. O resultado era a decadência cívica, em que o interesse privado se confunde com o interesse colectivo: "o espírito começa a entrever vagamente um ideal elevado e grande, mas o carácter ziguezagueia, ainda na sua marcha trôpega e incerta, embriagada pelas ambições e pelos sentimentos egoístas. Em todas as épocas de decadência cívica se repete esta cena repugnante: a embriaguez da consciência"(105).

A forma como Luís de Magalhães repudiava os pressupostos do liberalismo económico, postos ao serviço de uma oligarquia que ele reputava materialista e egoísta, permite talvez concluir que a base do criticismo oitocentista residia, sobretudo, numa dimensão moral. Não se atacava tanto o progresso material, bem visível até 1890 , mas a ausência de políticas sociais de distribuição de riqueza, bem como a corrupção financeira da classe burguesa dominante e das suas clientelas ${ }^{(106)}$. O pragmatismo da classe política dominante conduzira a uma ruptura inevitável entre a ação política e a ética, uma vez que os processos daquela significavam "a negação de todos os princípios morais": "A moral prega a verdade: a política confessa a mentira. A moral preceitua a escrupulosa honestidade das aç̧ões: a política vive da relaxação e da corrupção. A moral impõe a inflexibilidade austera do dever: a política ziguezagueia tortuosamente entre baixas transigências" ${ }^{\prime \prime 107)}$.

Assumindo posição de centralidade no seu ideário, a questão da degenerescência moral, aduzida dos escritos do historiador, mas igualmente de Antero de Quental, conduz as suas propostas sobre o renascimento nacional para o campo da metafísica: a criação do homem moral, pois só com este a política se aproximaria do ideal de Bem e de Verdade ${ }^{(108)}$. Se a

(105) Idem, Ibidem.

(106) "Todos nós sabemos o que o país quer: que se administre com probidade e dentro dos recursos do tesouro; que os homens públicos sejam honestos, sinceros e dedicados ao serviço do Estado; que se não aperte demais o arrocho tributário; que haja ordem e que se faça justiça" (Tarde, ano X, $\mathrm{n}^{\circ} 2872,30 \mathrm{Jun}$. 1897 , p. 1).

(107) "Notas políticas - política e políticos", Tarde, Ano X, n²858, 9 Jun. 1897, p. 1.

${ }^{(108)}$ Cf. Fernando Catroga, O Problema Político em Antero de Quental. Um Confronto com Oliveira Martins, p. 117. 
decadência radicava nas faltas dos homens, a regeneração política só podia consumar-se pela regeneração do homem ${ }^{(109)}$. Nessa perspectiva, só uma "revolução moral" poderia, por um esforço ingente de "abnegação cívica", conduzir o país para a superação das causas da crise, através da edificação de uma sociedade governada pelos pressupostos da ética e da moral: "Sinceridade, dignidade, respeito próprio, desinteresse pessoal acima de qualquer suspeita, espírito de sacrifício, resolução firme, um ardente patriotismo, um sentimento de justiça e um grande coração - eis o que é preciso para a grande revolução moral a operar"(110). Em última análise, a revivificação do país exigia a instauração de uma eticocracia.

Da severidade do juízo exprobratório com que mediram e avaliaram a conduta dos políticos coevos, resultou o pessimismo antropológico com que Luís de Magalhães anatematizou o século XIX, apodando-o de século "moralmente inferior". Daqui resulta que, para o herdeiro de José Estêvão, como aliás para Oliveira Martins ${ }^{(111)}$, cabia a uma elite moralmente superior o desafio de avançar para as reformas necessárias com que se inverteria a lógica decadentista. Essa elite estava aliás perfeitamente identificada e conotada com a geração dos "vencidos", e sobre ela recaía a responsabilidade de derramar sobre os espíritos a "ideia" regeneradora, estabelecida a partir de um fundo ético e nacionalista, com vista à reforma das instituições públicas, a começar pelos partidos políticos: "No meio deste achatamento geral sobressaem, contudo, algumas culminâncias morais e intelectuais. São elas o núcleo dos futuros agrupamentos políticos, que uma nova ordem de ideias, uma nova ordem de interesses colectivos hão-de vir a formar dentro da sociedade portuguesa"(112). Sabemos já que a formação de um partido de elite constituiu mais uma aspiração de alguns, como Luís de Magalhães, do que uma forte possibilidade de realização. Todavia, ao enunciar e reclamar o intervencionismo de uma elite, Magalhães era coerente com as asserções do seu período positivista da fase juvenil, ao reclamar para

${ }^{(109)}$ Cf. A Província, VI ano, $\mathrm{n}^{\circ} 25,31$ Jan. 1890, p. 1.

${ }^{(110)}$ Tarde, $\mathrm{X}$ ano, $\mathrm{n}^{\circ} 2858,9$ Jun. 1897, p. 1.

(111) Cf. Fernando Catroga, O Problema Político em Antero de Quental, p. 115.

(112) "O baralho político", O Repórter, I ano, n 32, 1 Fev. 1888, p. 1. 
a qualidade do ambiente mental e cultural as responsabilidades pelo progresso da nação(113).

2. O Portugal Contemporâneo e a História de Portugal foram das obras de autores portugueses que mais marcaram Luís de Magalhães e todos aqueles que interpretaram a história do país de acordo com a teoria do ocaso. Para Luís de Magalhães, porém, os livros do mestre significaram a verdadeira compreensão da realidade por detrás do vocábulo "patriotismo". Ele próprio o reconhece no artigo necrológico que escreveu pouco depois da morte do historiador, em 1894: "Ele foi, de facto, o genial biógrafo da alma portuguesa. Nunca no meu espírito se apagará a impressão que senti ao ler a História da Civilização Ibérica e História de Portugal. O fôlego épico duma e a emoção dramática da outra como que me insuflaram um patriotismo novo, não um patriotismo retórico, cegamente optimista, um chauvinismo alimentado pelo culto irreflectido de tradições deformadas, mas um patriotismo, por assim dizer, realista, um patriotismo que dos males, das misérias, dos desastres e infortúnios da Pátria, tira, tanto quanto das suas glórias, razões e motivos para a amar amarguradamente"(114).

A questão do patriotismo revela-se primacial para penetrar no conhecimento da psicologia individual de Luís de Magalhães, como, aliás, de toda a geração emergente em 1880. Efectivamente, as comemorações camonianas, em 1880, concitaram o nascimento de todo um movimento colectivo em torno da construção de uma "consciência nacional" que o liberalismo ainda não concebera. Curiosamente, as obras de Antero de Quental, Oliveira Martins e Teófilo Braga revelavam-se fundamentais na estruturação deste movimento ${ }^{(115)}$.

${ }^{(113)}$ No seu estudo "Há na sociologia fenomenalidade natural? Ideia de lei em sociologia" (Coimbra, 1880), Luís de Magalhães conclui, após rigorosa observação dos factos ao longo da história, que "todo o movimento social pressupõe-se antecedido de uma elaboração mental, a que o prendem necessárias correlações de causalidade; mais simples: $O$ estado mental determina o estado social" (pp. 20-22).

(114) Campo Santo - Artigos Críticos Sobre as Mais Notáveis Figuras Literárias e Políticas dos Séculos XIX e XX em Portugal, Coordenação de Miranda de Andrade, Braga, 1971, p. 72.

${ }^{(115)}$ Cf. Rui Ramos, ob. cit., p. 38. 
A emergência da consciência política de Luís de Magalhães deve pois conotar-se com este movimento nacional de afirmação patriótica. Toda a sua vida política será concebida em função do amor pela pátria, esse "amar amarguradamente" que cultivou ao lado do seu mestre e sob o céu da memória de seu pai. Como convém a um espírito sensível, estribado no idealismo poético com que revestia a actividade política, o patriotismo encerrava um forte significado moral, que exigia o sacrifício do interesse individual ao bem comum. "O político não se pertence a si, pertence ao seu país. Só assim ele poderá ser grande" afirmava ele aos vinte anos numa carta à sua mãe, Rita Miranda de Magalhães ${ }^{(116)}$. Isto ajuda-nos a compreender melhor por que é que, após o fracasso da "vida nova", só da pátria ele admitiu os "sacrifícios" que o tiravam do sossego da sua Quinta e da actividade literária ${ }^{(117)}$. O patriotismo transformava-se em Magalhães num imperativo ético-moral, em função do qual o exercício das actividades política e cívica se apresentava como resultado de um dever de consciência, ditado por um sentimento de amor patriótico ao colectivo.

Esta prévia explicitação predispõe-se a esclarecer algumas das atitudes de Luís de Magalhães durante a reacção emocionada aos acontecimentos de 1890. Só assim entendemos que tenha partido do inquilino do Mosteiro a oferta de maior pecúlio - nada mais do que um conto de réis, um ano do seu rendimento bruto ${ }^{(118)}$ - para a subscrição nacional que visava a compra de um cruzeiro com que ingenuamente se quis combater a Inglaterra. A conotação do acto da subscrição com o ideal patriótico fixou-a ele próprio numa página de $A$ Província: "Do que se trata sobretudo, é de dar a prova real e solene, de estatuir o padrão aferidor do nosso patriotismo. [...] A subscrição nacional será o padrão mais alto que a nossa geração poderá deixar de si, na história do doloroso transe que atravessamos. [...] É possível que amanhã tenhamos que dar a nossa vida pela Pátria. Provemos desde já que somos capazes disso - sacrificando-lhe, primeiro, os nossos interesses e os nosso haveres" ${ }^{\prime(119)}$. No fervor

${ }^{(116)}$ BNL, Espólio de Luís de Magalhães, E2/cx. 36.

(117) "E aí tem - já que o meu caso o interessa - porque eu descuro as letras, que amo, e me envolvo na política, que me aborrece. Imposições do meu moralismo - que cada vez mais se me fixam no espírito como o prisma essencial e primacial da vida" (Lopes d'Oliveira, ob. cit., pp. 361-365).

${ }^{(118)}$ Cf. Idem, ibidem.

(119) A Província, Número extraordinário pela Pátria, Jan. 1890, p. 1. 
patriótico procurava o poeta, o idealista, encontrar o antídoto para a decadência nacional, combatendo a corrupção e o interesse particular, que almejava substituir pelo "sentimento pátrio" e pelo "amor da raça" com que sonhava conduzir o país a "novos destinos" e uma "vida nova" (120). O ultimato inglês apresentava-se, assim, como a "catástrofe regeneradora" tão esperada no seio da geração de 70 como em Luís de Magalhães ${ }^{(121)}$.

A própria Liga Patriótica do Norte, embora irrompesse como uma "ideia vaga e indefinida", constituía para Magalhães, naquele momento, a única âncora de salvação com garantias de agremiar todos os verdadeiros patriotas: "Pareceu-me pois, que levantar uma bandeira, cujo lema estrito fosse a palavra Pátria, em meio dessa desordem, que parecia haver já subvertido a própria Autoridade - seria oferecer um ponto de junção a todos os bons elementos, sinceros e desinteressados, que esgotavam as suas forças numa convulsão anárquica" (122). No final, o esforço emprestado ao projecto regenerador da Liga Patriótica não resistiria, nas palavras de Magalhães, à ausência de "combustível moral": "O incêndio patriótico fora um fogo de palha: clarão dum momento"(123).

Passados breves meses de inebriante e generoso patriotismo, com que o ultimatum contagiou a nação, Luís de Magalhães regressará ao pessimismo dilatado com que avaliava o seu tempo. Na verdade, os ensinamentos da história, não apenas os de Martins, mas igualmente os de Alexandre Herculano, conduziram-no à sublimação do período da história de Portugal que antecedeu os Descobrimentos. Foi nesse período idílico que um rasgo de homens guerreiros e trabalhadores construíram uma nação. O sentimento patriótico dessa época dourada, forjado no trabalho colectivo, era enaltecido como exemplo para os tempos modernos: "A justiça, a administração, a instrução, a indústria, o comércio, a agricultura, desenvolvem-se florescentemente. Esse trabalho rude e áspero liga os homens entre si, dando-lhes, na solidariedade dos esforços, o senti-

${ }^{(120)}$ A Província, VI ano, $\mathrm{n}^{\circ} 21,27$ Jan. 1890 , p. $1 ; \mathrm{n}^{\circ} 25,31$ Jan. 1890, p. 1

(121) "Mas é que a verdade é esta: o conflito com a Inglaterra pode ser para nós providencial" (A Provincia, Ano VI, $\mathrm{n}^{\circ}$ 17, 22 Jan. 1890, p. 1).

(122) Luís de Magalhães, Antero de Quental. In Memoriam, 1896, p. 132. Sublinhado no original.

(123) Idem, ibidem, p. 134.

(124) Notas e Impressões, 1890, pp. 61-66. 
mento moral duma pátria"(124). A sedução de Luís de Magalhães por esta época radica no facto de as "origens" de Portugal representarem, como mostrava Herculano, a época em que os povos mais se teriam "aproximado da sua essência" e se transformaram em povos modernos ${ }^{(125)}$.

Esta leitura da história nacional, em que os séculos da fundação surgem enaltecidos graças ao árduo trabalho com que se "conquista", "povoa", "edifica", "semeia" e "cultiva", servirá a Oliveira Martins, como ao seu discípulo, para defender um nacionalismo económico que tinha como base a produção nacional ${ }^{(126)}$. Para Magalhães, o ressurgimento nacional só aconteceria por efeito da "emancipação industrial do estrangeiro" e pela "nacionalização do trabalho". A exaltação patriótica de 1890 levou-o mesmo a cometer alguns desvarios de nacionalismo radical: "Ponhamos um travão à desmedida influência exótica. Vivamos de nós e para nós. Nacionalizemo-nos. Expurguemos a vida portuguesa de toda a estrangeirice corruptora do nosso carácter histórico"(127).

Se desvalorizarmos os excessos de linguagem, justificados pelo ambiente em que foram produzidos, surpreendemos na valorização do mundo rural a consonância de Luís de Magalhães com o palpável

(125) Fernando Catroga, "Alexandre Herculano e o Historicismo Romântico", in História da História em Portugal, Sécs. XIX-XX, Lisboa, Temas e Debates, 1998, p. 81 .

${ }^{(126)}$ Cf. Política e Economia Nacional, Porto, 1885.

${ }^{(127)}$ A Província, VI ano, $\mathrm{n}^{\circ} 17,22$ Jan. 1890, p. 1 . O mesmo sentimento nacionalista despertará na literatura, associado normalmente ao neogarrettismo conotado, entre outros, com Alberto de Oliveira. Ora muito antes deste, Luís de Magalhães censurava nas páginas de $A$ Província a "desnacionalização da nossa literatura" e dava como exemplo o "esquecimento completo, o lamentável abandono em que se tem deixado todo o riquíssimo tesouro das nossas lendas, das nossas tradições, da nossa história" (Notas e Impressões, pp. 67-73). Depois de elogiar Garrett e Herculano pelos seus "ímpetos de génio", o autor debruça-se sobre o poema "A nau Catrineta". Desta "história dos trabalhos, dos sofrimentos e das superstições dum povo de marinheiros" poderia, afirma o escritor, "fazer-se brotar um verdadeiro poema nacional". E termina condenando a excessiva influência francesa: "Basta já de pestichar os modelos franceses, de pedir emprestados a estrangeiros as suas lendas, a sua vida, os seus sentimentos, os seus processos, [...] as suas formas poéticas. [...] Tonifiquemos o espírito na límpida nascente das nossas tradições literárias, como num banho de água viva" (ibidem). A nacionalização da literatura visava, deste modo, contribuir para a construção do sentimento patriótico em Portugal. 
pessimismo em que viviam mergulhados os intelectuais do seu tempo. Grande proprietário rural e agricultor, o poeta experimentava na lavoura mais do que uma forma de produzir riqueza. Encontrava na vida do campo a sua paz interior e um modo de vida que se coadunava com a sua natureza de poeta, tantas vezes glosada por Eça de Queirós ${ }^{(128)}$. Era na vida rural que o poeta procurava refúgio para o político, para o idealista, e escondia o seu pessimismo. Ele próprio o reconhecerá em 1908, em carta ao Conde de Arnoso, seu companheiro de amarguras políticas, depois do trágico episódio do assassinato régio: "Eu tive a suprema felicidade de ter, superior à paixão dos homens, a paixão da natureza. Entrei na política por um puro acaso, mantive-me nela por dever. Fui vencido em todas as campanhas, em que me aventurei: Vida Nova, com Oliveira Martins, Liga Patriótica com o Antero, agora o franquismo, liquidado numa tragédia. Tudo isto me faria, concerteza o mais azedo dos homens, o mais intratável misantropo, se eu não visse, por baixo do Portugal político, o Portugal rural, esta linda terra, onde a nossa raça vive há tantos séculos lavrando e cantando, [...]. A solidão, os livros, a terra e a nossa ninhada em volta de nós - eis o supremo refúgio"(129). Esta exaltação da vida rural, tão do agrado de Luís de Magalhães, nasceu do romantismo, em Garrett e Herculano, e sobreviveu em intelectuais ilustres como Guerra Junqueiro ou António Nobre, prolongando-se no salazarismo, associada a um certo culto nacionalista e patriótico de Portugal $^{(130)}$. Será talvez um inquietante sinal das dificuldades de Portugal em trilhar os caminhos da modernidade.

3. Mas fora das aspirações de quietude reveladas pela glorificação do mundo rural, as elites culturais do fim do século XIX envolveram-se em febris manifestações de nacionalismo ideológico. Curiosamente, uma das manifestações que adquiriu maior ímpeto foi um renovado sebastianismo cultural e político.

(128) "Como Ulisses, ancorei, a caminho em várias paragens. Primeiramente em Moreira, onde o nosso possante Luís, enquanto não endireita a nação, ora se ocupava a endireitar o seu trigo, como compete a um lavrador, ora, como cumpre a um poeta, a endireitar as suas roseiras" (carta de Eça de Queirós ao Conde de Arnoso, 1899; cf. igualmente, carta de Eça de Queirós a Luís de Magalhães, BNL, Espólio de Luís de Magalhães, E2/cx. 1/doc. 23).

${ }^{(129)}$ Carta de 29 de Fevereiro de 1908, BNL, Espólio de Luís de Magalhães, E2/cx. 36.

${ }^{(130)}$ Cf. Eduardo Lourenço, ob. cit., p. 59. 
Com efeito, o sebastianismo ganhou um novo enfoque na interpretação da História de Portugal de Oliveira Martins, enquadrado numa ressurgência sebastianista na literatura e na cultura do fim do século XIX e princípios de $X X^{(131)}$. $O$ fenómeno apresenta-se, agora, mascarado sob duas emanações: por um lado, a crença no regresso em $D$. Sebastião ou noutro salvador político; por outro, enquanto pura manifestação de gesta estética ou literária, bem como lado visível de um lato conjunto de atitudes culturais associadas ao mito ${ }^{(132)}$. Em Luís de Magalhães combinam-se as duas esferas do fenómeno: significa a crença no regresso de um "messias" político, tão ao gosto desta elite cultural em que participa no fim do século XIX, consubstanciada numa certa atitude política e cultural, que só pelo sebastianismo pode ser cabalmente penetrada.

O primeiro contacto de Magalhães com a interpretação da temática sebastianista resultou, inevitavelmente, da leitura de Oliveira Martins. Magalhães consideraria a ressurgência da "teoria da história do sebastianismo" como um "dos mais fulgurantes rasgos de génio" do autor da História de Portugal (133). Mas o despertar da simbólica sebastianista encontramo-lo, muito cedo, no dealbar da sua actividade poética. Foi no poema As Navegações, versos recitados no Teatro Académico de Coimbra aquando da inauguração do monumento a Luís de Camões, em 1881. No dito poema, o Épico é associado a uma época de glória, quando o patriotismo dos grandes heróis conduziu o país a realizações magnificentes. O sebastianismo de Magalhães é desde cedo associado a uma saudade de um passado glorioso. Por isso se pretendia que a esperança regeneradora ressurgisse pela mão da mesma força que nos conduziu ao mar, força que exigia agora o mesmo heroísmo, num combate prenhe de similitude mas distinto, pois as naus e os canhões de outrora viam-se agora substituídos pela ciência e pelo progresso:

${ }^{(131)}$ Cf. Joel Serrão, Do Sebastianismo ao Socialismo, $3^{\text {a }}$ ed., Lisboa, Livros Horizonte, 1973, pp. 9-11.

(132) Cf. António Machado Pires, D. Sebastião e o Encoberto, 2a ed., Lisboa, Fundação Calouste Gulbenkian, 1982.

(133) Luís de Magalhães, D. Sebastião, Coimbra, França Amado Editores, 1898, p. 252. 
“Ávante, ávante, pois! Nem tudo se acabou!

Desde então para cá a História transformou

As armas do combate. É outro agora o mundo,

É outra agora a luta e outro o mar profundo

Sobre o qual temos de ir, soldados triunfantes,

Desfraldar no Futuro os pavilhões radiantes!

Brame em torno de nós o mar do Pensamento

Em cuja imensidão um prodigioso vento,

O vento do progresso impele a nau da Ideia"(134).

Os evidentes apelos de Magalhães ao "combate", com vista a evitar a derrocada, apelando ao antigo espírito empreendedor, são esclarecedores quanto aos desejos do poeta em associar o espírito sebástico a um certo apelo mobilizador da opinião pública esclarecida.

O elogio do poema, escrito pelo amigo e mestre Oliveira Martins, inserto no prólogo que o historiador preparou para o livro Odes e Canções, a que já fizemos referência, não deixa dúvidas quanto à importância do sentimento sebástico para o próprio historiador, numa época em que este se preparava para anunciar ao país a sua candidatura a "messias": "D. Sebastião é o único assunto capaz de inspirar um grande poema português. Choramos ainda hoje as lágrimas do século XVI, esperamos ainda o dia da redenção... [...] O futuro poema de Luís de Magalhães ${ }^{(135)}$,

(134) Luís de Magalhães, As Navegações, Versos recitados no Teatro Académico no sarau literário celebrado na véspera da inauguração do monumento a Luís de Camões, Coimbra, Livraria Central de J. Diogo Pires, 1881, p. 19. O poema termina com um convite ao velho espírito de acção nacional: "Ó velho Portugal, ávante nesse Mar!/Com a crença do Bem em nossos corações/Um outro Novo Mundo iremos conquistar,/- que há-de ser a maior das glórias de Camões!" (ibidem, p. 19).

(135) $\mathrm{O}$ historiador refere-se provavelmente à disposição que o amigo lhe indicara de escrever um poema dedicado ao mito de D. Sebastião. Na correspondência entre ambos, tal como na correspondência de outros, como Eça de Queirós, Luís de Magalhães é desde esta altura várias vezes tratado por "meu caro sebastianista", sendo várias vezes questionado sobre o assunto. Na verdade, apesar de um poema intitulado "D. Sebastião" impresso na Revista de Portugal (vol. 2, pp. 672-679), só em 1898 o autor terminará o seu poema dedicado ao mito sebástico, integrado numa conjuntura de descrença e pessimismo que se seguiu à morte dos seus amigos Oliveira Martins e Antero de Quental e pelo agravamento da crise que se seguiu ao ultimato inglês. 
será aclamado por todos aqueles que só do sebastianismo esperam já agora a solução dos males da pátria e o ponto final das nossas atribulações" ${ }^{\prime \prime}(136)$. Estamos convencidos que Oliveira Martins se encontrava entre aqueles que "só do sebastianismo" esperavam o ressurgimento nacional, integrando essa elite intelectual que re-interpretava o sentido do mito cultural sebastianista numa perspectiva nacionalista.

De facto, o sebastianismo, tal como o historiador o interpretou, é indissociável de um certo profetismo messiânico que resulta da própria ideia de decadência. Ao analisar o papel do mito na definição da decadência do povo português, este não esqueceu de o equacionar enquanto esperança messiânica de redenção alicerçada no profetismo judaico ${ }^{(137)}$. Do diagnóstico decadentista emergirá uma aspiração redentora, de carácter messiânico, que influirá em largos sectores do escol intelectual ligado à geração dos "vencidos da vida". Isto é, o messianismo como atitude cultural e crença nas possibilidades do surgimento de um "salvador", foi cultivado no seio da elite intelectual que interpretava os sinais de crise do fim do século com crescente preocupação. Para Luís de Magalhães, e tantos outros, como o conde de Arnoso, Jaime de Magalhães Lima, Alberto Sampaio, Manuel da Silva Gaio, a procura de um messias político constituiu apreensão permanente. E os messias compareciam à chamada: Oliveira Martins, D. Carlos, Mouzinho de Albuquerque e João Franco integraram o santuário da hagiografia redentora, em nome da pátria que agonizava. Sobre Martins dirá Luís de Magalhães em 1892, quanto este ascendeu finalmente à tribuna ministerial: "a minha fé no seu talento, no seu saber, no seu tino prático, no seu génio administrativo, na surpreendente fecundidade dos seus recursos intelectuais, na sua energia de trabalhador, é de tal forma profunda e arreigada, que para mim V. continua constituindo a derradeira esperança de salvação d'este pobre

${ }^{(136)}$ Oliveira Martins, "Prólogo", in Luís de Magalhães, Odes e Canções, Porto, Magalhães e Moniz Editores, 1884, pp. XXII-XXIV.

(137) Para uma análise do significado do sebastianismo martiniano veja-se Fernando Catroga, "História e Ciências Sociais em Oliveira Martins", in ob. cit., pp. 169-173 e António José Saraiva, ob. cit., p. 102 ss. 
e malfadado país"(138). O próprio republicanismo não escapou à liturgia messiânica, encarnando na república a verdadeira redenção(139).

Intérprete fiel desse sentimento colectivo, o $D$. Sebastião de Luís de Magalhães, publicado em 1898, significava a emergência "de um sentimento do nosso tempo, em que o presente desagrada aos melhores espíritos e em que todos os que têm na alma uma centelha de crença apelam para o incerto futuro, esperando cada um pelo $\mathrm{D}$. Sebastião do seu ideal"(140); ou seja, o D. Sebastião, tal como antes o poema As Navegações, pode ser interpretado como um derradeiro apelo de mobilização política, agora motivado para a definição de uma liderança carismática de sentido moderno. $\mathrm{O}$ "Capitão de Cristo" é tomado como símbolo duma futura regeneração, porque ele resume "o génio antigo da Raça"(141). O espírito heróico revelado pela nação até ao século XVI é convocado para a regeneração da pátria, de forma que o sebastianismo de Luís de Magalhães projecta o passado glorioso num futuro que se pretende radiante: "O sebastianismo é, desta forma, a expressão alegórica desse patriotismo, elegiacamente saudoso do Passado, mas sempre firme na esperança numa próxima ressurreição do génio antigo - desse patriotismo idealista, sempre em dissidência com o Presente, sempre de olhos fitos no Futuro"(142).

${ }^{(138)}$ Carta de Luís de Magalhães a Oliveira Martins, de 18 de Janeiro de 1892, in Moreira das Neves, O Grupo dos Cinco-Dramas Espirituais, Lisboa, Bertrand, 1945, pp. 172-174.

${ }^{(139)}$ O próprio Luís de Magalhães considerara que o republicanismo português, sendo caracteristicamente instintivo, enquanto "protesto moral", constituía "uma nova forma apenas de messianismo histórico" (Revista de Portugal, vol. 3, p. 625).

${ }^{(140)}$ D. Sebastião, p. 256. Para uma interpretação do livro de Luís de Magalhães veja-se Alberto Sampaio, Estudos Históricos e Económicos, vol. II, Porto, Livraria Chandron, 1923, pp. 105-110.

${ }^{(141)} \mathrm{O} D$. Sebastião de Luís de Magalhães, contrariamente a outros poemas sobre o mito, faz regressar o rei mártir, sob a forma de "encoberto", para cumprir a sua "penitência". Durante esse regresso, em que atravessa Portugal até ao presente, o "desejado" toma contacto com a decadência do país sob as suas múltiplas facetas (Cf. p. $115 \mathrm{ss}$ ).

${ }^{(142)}$ Ibidem. 
A assunção do sebastianismo enquanto evangelho mobilizador parece confirmar-se pelo teor de uma missiva que Magalhães dirigiu a João Franco, a propósito do seu livro. Nela o poeta defende, com ardor indomável, a irrepreensível necessidade de uma acção enérgica e heróica, muito ao estilo romântico, como prova o remate acerca da eventual morte da nacionalidade: "Para o fundo mas salvando a honra da Pátria! Aí tens o caso dessa quadra que tanto te impressionou:

\section{Bendito aquele que por sua crença pura \\ Cai com honra e valor! \\ Bendito! Que ao vencido o heroísmo transfigura \\ Tornando-o um vencedor!"(143).}

Na mesma carta a João Franco, Luís de Magalhães declara ser "urgente dar um grande exemplo e tomar uma grande atitude"(144). Os acontecimentos futuros tenderão a confirmar este desejo de intervenção para resolver a grave crise económico-financeira da época. Em Dezembro de 1898 reunia-se em casa de Luís de Magalhães um punhado de notáveis, com destaque para Mouzinho de Albuquerque, Alberto Sampaio e Jaime de Magalhães Lima. Apesar das conotações do movimento dos endireitas com a emergência de um programa autoritário com vista à reforma do Estado, a sua verdadeira essência, aquela que é corroborada pelos documentos e textos da época, reside na formulação de um enérgico programa de saneamento financeiro ${ }^{(145)}$.

Já a definição de uma liderança carismática parece conexionar-se, pensamos nós, com o ressurgimento da teoria do engrandecimento do poder régio, de que Luís de Magalhães foi principal responsável. Uma iniciativa que correspondeu a uma consciente formulação doutrinária com vista à re-fundamentação das competências atribuídas ao monarca pela Carta Constitucional. Com efeito, o autor do Brasileiro Soares permanecerá fiel

${ }^{(143)}$ Carta de Luís de Magalhães a João Franco, s.d., BNL, Espólio de Luís de Magalhães, E2/cx. 36.

(144) Ibidem .

${ }^{(145)}$ Cf. artigos de Luís de Magalhães no jornal Tarde entre 30 de Janeiro e 15 de Março de 1899; e ainda Luís de Magalhães, $A$ Dívida e o Déficit, Lisboa, Imprensa Nacional, 1900. Na mesma carta a João Franco, dirá Magalhães: "Não me parece isto perdido [...]. Ainda estou em que é uma pura questão de administração" (BNL, E2/cx. 36). 
ao pressuposto martiniano, cultivado igualmente por Eça ou Antero, de que a reforma do Estado liberal devia encontrar a sua inspiração político-ideológica na produção de uma elite encabeçada pelo rei. Era a revolução de cima para baixo.

O seu Príncipe, como ele o apelidaria, não chegou a ver a luz do dia por intervenção directa do Conde de Arnoso, secretário particular do monarca ${ }^{(146)}$. Porém, cremos ser possível aceder ao conteúdo do seu "tratado" político-doutrinário por via indirecta. Na verdade, estamos convencidos que o opúsculo Eduardo VII, publicado em $1910 \mathrm{em}$ homenagem ao monarca britânico, dará publicidade à doutrina antes reprovada pelas cautelas do Paço.

A antiga fórmula liberal, defendida por Thiers, segundo a qual "o rei reina, mas não governa" é aqui objecto de nova interpretação, na medida em que o acto de reinar será amplamente sublimado.Enquanto a acção governativa era entendida como simples instrumento de execução das leis aprovadas, reinar significava "predominar, influir, guiar duma forma genérica, dirigir alto, por meio da acção moral que compete à alta magistratura da Coroa, as coisas da administração e a marcha geral da política"(147). A acção pessoal do monarca surgia enaltecida enquanto "inspiração da consciência", rejeitando Magalhães, por isso mesmo, "as fúrias do leão" e as "astúcias da raposa" como primado das virtudes régias. O Príncipe moderno deveria operar a partir de critérios morais, perfilando-se como o primeiro zelador dos interesses da nação: "o espírito de justiça, a mais larga abnegação, a autoridade moral, a energia calma e firme, a decisão pronta, o senso prático, o instinto da oportunidade, a prudência, a discrição, o tacto, juntos aos conhecimentos das coisas e ao uso dos homens - eis [...] as qualidades essenciais d'aquele que tem de dirigir multidões, interpretar sentimentos colectivos [...] conciliar divergências, sofrear ambições ilegítimas [...] estimular dedicações patrióticas [...] equilibrar interesses [...]"(148). No elogio ao monarca inglês, Luís de Magalhães enuncia o estilo de intervenção monárquica que gostaria de ver concretizado em Portugal.

${ }^{(146)}$ Cf. Carta de Luís de Magalhães ao Conde de Arnoso, BNL, Espólio de Luís de Magalhães, E2/cx. 36, de 8 de Agosto de 1898.

(147) Luís de Magalhães, Eduardo VII, Porto, 1910, pp. 31-32

(148) Ibidem, p. 33. 
Significa isto que, fora dos arraiais republicanos e dos partidos dinásticos, as aspirações dos reformistas guardaram para D. Carlos um protagonismo e uma liderança que ele procurou sempre adiar, preso aos liames constitucionais, fiel aos corifeus do rotativismo. Na lógica da simbologia sebástica, D. Carlos seria o "Capitão de Cristo", o "Encoberto", por quem se suspirava para fazer regressar a Pátria ao "Sucesso"(149).

Consequentemente, não julgamos possível enclausurar o sebastianismo, tal como o formulou o discípulo de Oliveira Martins, na muralha criativa da sensibilidade individual. O seu $D$. Sebastião tanto espelha as amarguras de uma alma dilacerada pelos infortúnios da pátria como empresta dimensão cultural e amplifica uma ambição reformadora que pretende estimular, acima de tudo, as elites dirigentes e a intelligentsia nacional.

Ora o monarca viria realmente a ser contagiado pela política intervencionista promovida por uma certa cultura política, emergente com os "vencidos da vida", e que ressurgia agora pelo lápis de um dos principais teorizadores do franquismo. O esforço de compreensão deste movimento de aspiração reformista exigirá, pois, um estudo mais atento dos contributos doutrinários e políticos de alguns dos seus mais preeminentes signatários. Luís de Magalhães merece, seguramente, um lugar de destaque.

${ }^{(149)}$ Luís de Magalhães, D. Sebastião, p. 256. Já depois da morte de D. Carlos, não deixará de se referir criticamente às suas qualidades de monarca: "Perdeu-o a sua fraqueza moral, a sua apatia, a sua indiferença política, a sua cega fidelidade aos seus primeiros-ministros" (Carta ao Conde de Arnoso, de 13 de Julho de 1908, BNL, Esp. E2/Cx. 36). 